\title{
ARTICLES
}

\section{Geochronology of Paleoproterozoic Augen Gneisses in the Western Gneiss Region, Norway: Evidence for Sveconorwegian Zircon Neocrystallization and Caledonian Zircon Deformation}

\author{
Torkil S. Røhr, ${ }^{1, \star}$ Bernard Bingen, ${ }^{1}$ Peter Robinson, ${ }^{1}$ and Steven M. Reddy ${ }^{2}$ \\ 1. Geological Survey of Norway, P.O. Box 6315 Sluppen, 7491 Trondheim, Norway; 2. Institute for Geoscience \\ Research, Department of Applied Geology, Curtin University, G.P.O. Box U1987, Perth, \\ Western Australia 6845, Australia
}

\begin{abstract}
A B S T R A C T
The Western Gneiss Region, western Norway, consists of Paleoproterozoic crust of Baltica ancestry (Baltican Basement), partly subducted to high- and ultrahigh-pressure (HP-UHP) conditions during the Scandian Orogeny between 415 and $395 \mathrm{Ma}$. The dominant felsic gneisses carry little evidence for the HP-UHP history but were affected by amphibolite-facies reworking during exhumation. Laser ablation-ICP-MS and secondary ion mass spectrometry (SIMS) zircon $\mathrm{U}-\mathrm{Pb}$ data collected in augen gneiss samples constrain the magmatic and metamorphic geochronology in this crust. Five samples from the eclogite-bearing HP-UHP basement near Molde yield intrusion ages ranging from $1644 \pm 6$ to $1594 \pm 10 \mathrm{Ma}$. Two samples of the structurally underlying eclogite-free basement yield ages of $1685 \pm$ 18 and $1644 \pm 13 \mathrm{Ma}$, and a sample from the infolded Middle Allochthon Risberget Nappe yields an equivalent age of $1676 \pm 18 \mathrm{Ma}$. Two samples of the eclogite-bearing basement contain low $\mathrm{Th} / \mathrm{U}$ neocrystallized zircon with an age of $950 \pm 26 \mathrm{Ma}$. This zircon provides the northernmost direct evidence for at least amphibolite-facies Sveconorwegian metamorphism in unquestionable Baltica crust, close to the known "Sveconorwegian boundary" in the Western Gneiss Region. The Western Gneiss Region (1686-1594 Ma magmatism), the Eastern Segment of the Sveconorwegian Orogen (1795-1640 Ma magmatism), and the Idefjorden terrane hosting the type Gothian active margin magmatism (1659-1520 Ma) probably represent three distinct Proterozoic growth zones of Baltica into which Sveconorwegian reworking propagated. Samples of the eclogite-bearing basement lack Scandian neocrystallized zircon but do show partial recrystallization of zircon. Paired cathodoluminescence and electron backscatter diffraction images indicate that zircon crystals underwent crystal-plastic deformation during the Scandian subduction-exhumation cycle. They illustrate a relationship between crystal-plastic deformation by dislocation creep, fading of oscillatory growth zoning, and loss of radiogenic lead.
\end{abstract}

Online enhancements: appendix, supplementary material.

\section{Introduction}

Scattered evidence for Grenvillian-Sveconorwegian orogenic events is found within the Caledonides of Scandinavia, Svalbard, and Greenland (Kalsbeek et al. 2000; Røhr et al. 2004; Kirkland et al. 2006; Corfu et al. 2011). The distribution and character of Grenvillian-Sveconorwegian magmatism and metamorphism bring important arguments to the

Manuscript received November 3, 2011; accepted November 20, 2012.

* Author for correspondence; e-mail: torkil.rohr@ngu.no. reconstruction of pre-Caledonian history in the North Atlantic regions. The Western Gneiss Region (WGR) represents a large (ca. 40,000 km²) window of mainly Paleoproterozoic Baltica crust exposed in the Caledonides of western Norway (figs. $1,2)$. It corresponds to the northernmost exposure of a Sveconorwegian overprint in basement rocks of unquestionable Baltica ancestry (Tucker et al. 1990; Røhr et al. 2004). The WGR was partially subducted to high-pressure (HP) and ultrahigh-pressure (UHP) conditions during the Scandian Orog- 


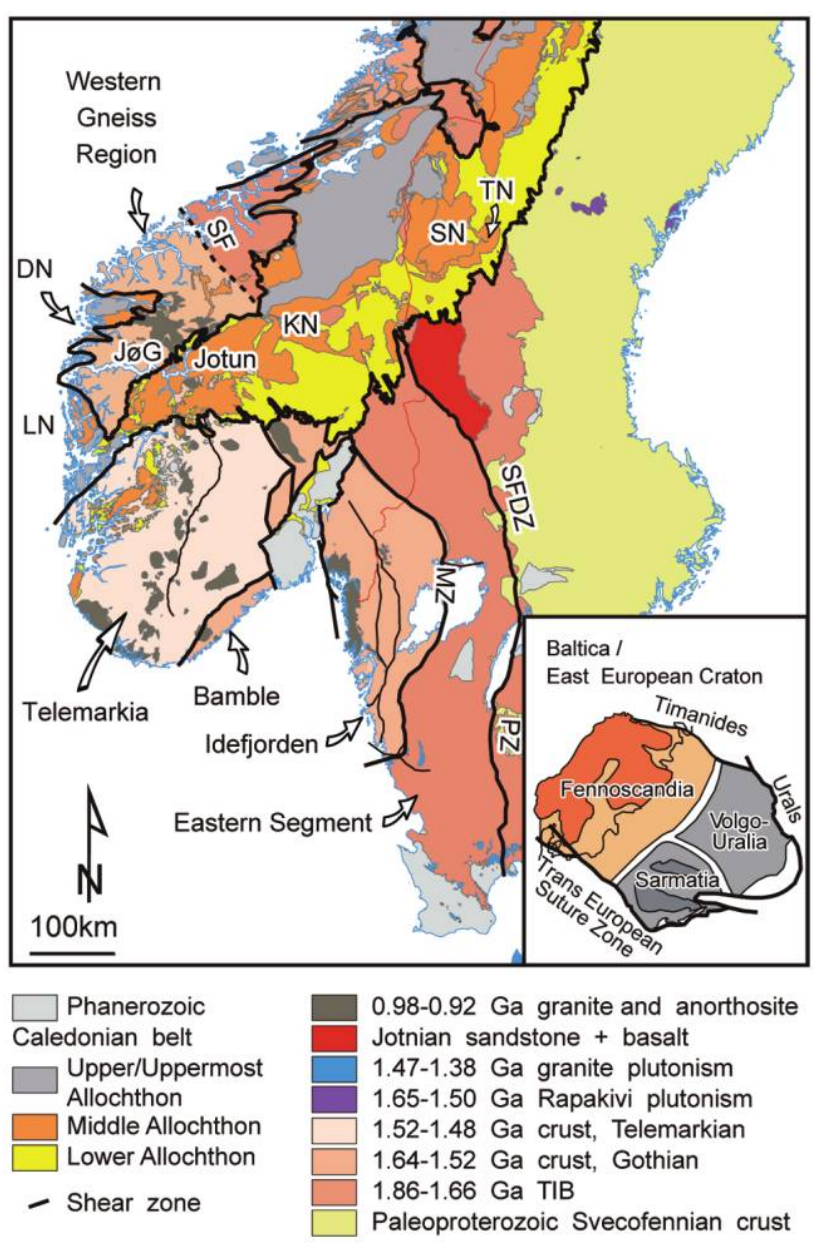

Figure 1. Map of southwestern Fennoscandia indicating the age of the various terrains mentioned in the text. DN: Dalsfjord Nappe; JøG: Jølster Granite; KN: Kvitvola Nappe; LN: Lindås Nappe; MZ: Mylonite zone; PZ: Protogine zone; SF: Apparent Sveconorwegian Front in the Western Gneiss Region; SFDZ: Sveconorwegian Frontal Deformation Zone; SN: Särv Nappe; TN: Tännäs Nappe.

eny and was later exhumed isothermally in the footwall of major detachment zones (review in Andersen 1998; Hacker et al. 2010). Eclogites record HP to UHP metamorphism (Cuthbert et al. 2000; Krogh Ravna and Terry 2004; Hacker 2006), while garnet peridotites attest to the interaction between crust and mantle (review in Brueckner et al. 2010). The voluminous Paleoproterozoic Baltican gneisses hosting eclogites and peridotites generally carry no or tenuous evidence for the HP to UHP history. During exhumation, the WGR was affected by amphibolite-facies deformation, which largely overprinted earlier structures and mineral assemblages especially in the less competent felsic rocks (Terry and Robinson 2003).

The dominant felsic orthogneisses have received much less attention than the eclogites and peridotites. Geochronological data available today indicate that they mainly formed during a comparatively short-lived Paleoproterozoic magmatic event between ca. 1690 and $1620 \mathrm{Ma}$ and were reworked during both the Sveconorwegian and the Caledonian orogenies (Tucker et al. 1990). Here we explore the zircon U-Pb geochronology of augen gneisses that have been interpreted as Mesoproterozoic (1520-1506 Ma) plutons intruding the $\mathrm{Pa}$ leoproterozoic crust (Lappin et al. 1979; Carswell and Harvey 1985; Tucker et al. 1990). We focus on the Molde area, which was affected by Caledonian UHP metamorphism (Terry et al. 2000a) and which is close to the northernmost reach of Sveconorwegian magmatism and metamorphism (Tucker et al. 1990). In terms of regional geology, this study has three objectives: (1) to investigate whether Mesoproterozoic magmatism occurred in this part of the WGR and, if so, correlate these events to other Mesoproterozoic events documented on Baltica; (2) to evaluate the extent of Sveconorwegian reworking of the basement in this part of the Caledonides; and (3) to evaluate the extent to which Caledonian HP to UHP metamorphism caused neocrystallization of zircon in felsic gneisses.

Several studies have shown how deformation related to meteorite impacts causes lead loss and in some cases complete resetting of the U-Pb system in zircon (e.g., Nemchin et al 2009; Cavosie et al. 2010; Kamo et al. 2011; Tohver et al. 2012). Deformation features in zircon produced at crustal strain rates have also been extensively documented (Timms et al 2006, 2012; Reddy et al. 2007, 2009; Austrheim and Corfu 2009). Although some studies have been able to demonstrate compositional variations associated with deformation microstructures (Reddy et al. 2006; Timms et al. 2006, 2011, 2012), very few studies have been able to demonstrate a relationship between lead loss in zircon and crystal-plastic deformation occurring at "normal" terrestrial strain rates (e.g., Moser et al. 2009). In addition to discussing the above-mentioned regional aspects, this study also offers an explanation to so-called ghost zoning (Hoskin and Black 2000) and substantiates a link between deformation and lead loss in zircon.

\section{Geological Setting}

The Scandinavian Caledonides formed in a sequence of events related to the collision between Baltica and Laurentia in the late Silurian (the Scandian Orogeny), including Early Devonian eclogitefacies metamorphism and exhumation locally tied 


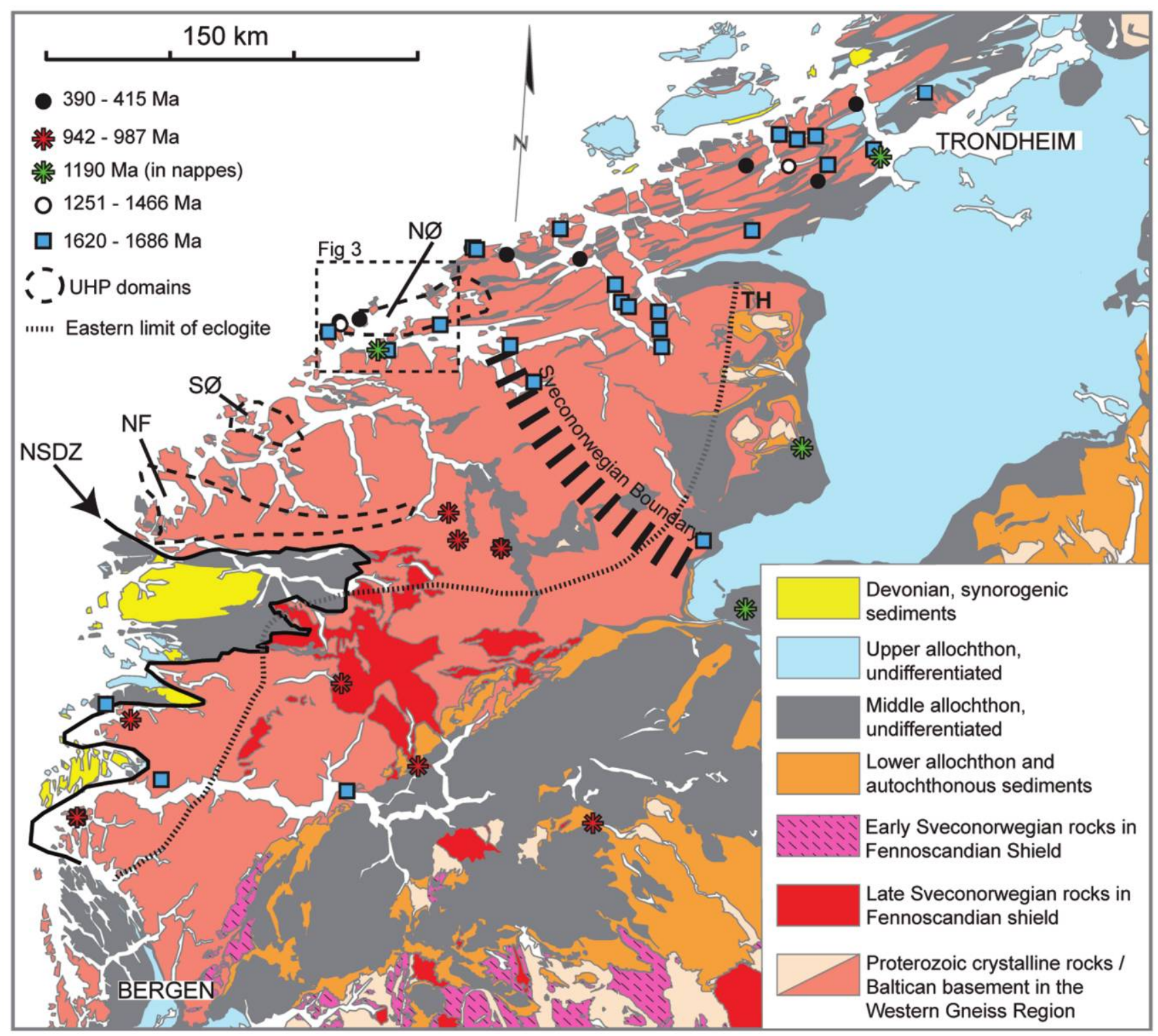

Figure 2. Simplified geologic map focusing on the Western Gneiss Region, Norway. Samples dated with the zircon $\mathrm{U}-\mathrm{Pb}$ method are located with circles, squares, or stars, depending on age. These are from Austrheim et al. (2003), Krogh et al. (2011), Skår and Pedersen (2003), Skår et al. (1994), Røhr et al. (2004), and Tucker et al. (1990, 2004). Also shown are the locations of ca. $1190 \mathrm{Ma}$ augen gneiss found within the Middle Allochthon (Handke et al. 1995; Lamminen et al. 2011). NF: Nordfjord UHP domain; NØ: Nordøyane UHP domain; NSDZ: Nordfjord-Sogn detachment zone; SØ: Sørøyane UHP domain; TH: Trollheimen.

to extensional detachment faults. They are composed of a pile of nappes transported southeastward and subdivided into the Lower, Middle, Upper, and Uppermost Allochthons. Basement of Baltica ancestry is exposed in a number of windows through the nappes, with rocks getting older northward along the orogen (e.g., Roberts and Gee 1985; Roberts 2003).

The WGR in western Norway is the largest of the basement windows in the Caledonides, and the dominant rocks are here referred to as the Baltican Basement (figs. 1, 2). The Baltican Basement is limited in the west by a late Scandian low-angle detachment, called the Nordfjord-Sogn Detachment Zone, and it is overlain in the southeast and east by a sequence of nappes. The Baltican Basement is mainly composed of quartz-monzonitic, granodioritic, and granitic orthogneisses, dated to between 
ca. 1690 and $1620 \mathrm{Ma}$ and associated with minor anorthosite, pyroxenite, gabbro, and paragneiss (fig. 2; Carswell and Harvey 1985; Tucker et al. 1990; Skår et al. 1994; Austrheim et al. 2003; Krogh et al. 2011). Geochemically, these orthogneisses are mainly alkali-calcic to calc-alkaline with slightly positive initial $\varepsilon_{\mathrm{Nd}}$ and $\varepsilon_{\mathrm{Hf}}$ values $\left(+1.2<\varepsilon_{\mathrm{Nd}(i)}<+\right.$ $\left.3.8 ;+0.6<\varepsilon_{\mathrm{Hf}(i)}<+5.0\right)$ and are interpreted to reflect active margin processes (Skår 2000; Austrheim et al. 2003; Lamminen et al. 2011). This Paleoproterozoic crust hosts Mesoproterozoic gabbro and metadolerite bodies (Austrheim et al. 2003; Tucker et al. 2004; Krogh et al. 2011) and peridotite bodies (Brueckner et al. 2010). Early Neoproterozoic (Tonian) granite plutons and pegmatites are present. The largest of these plutons, the Jølster granite, is dated to $966 \pm 3 \mathrm{Ma}$ (Skår and Pedersen 2003).

The intensity of Scandian metamorphism and deformation increases toward the northwest in the WGR (Griffin and Brueckner 1980; Terry and Robinson 2003; Hacker et al. 2010), in such a way that the WGR can be divided into a northwestern part hosting eclogite (HP and UHP domains) and a southeastern part lacking eclogite (fig. 2). Eclogites recording UHP conditions are observed along the northwestern coast in three discrete domains, called the Nordfjord, Sørøyane, and Nordøyane UHP domains (fig. 2; Wain 1997; Root et al. 2005; Vrijmoed et al. 2006; Hacker et al. 2010). Peak metamorphic conditions in these domains, estimated to $>800^{\circ} \mathrm{C}$ and $3.6 \mathrm{GPa}$ (Terry et al. $2000 a$; Kylander-Clark et al. 2007), were followed by isothermal decompression through amphibolite-facies conditions, commonly associated with partial melting (Labrousse et al. 2002; Root et al. 2005). The most prominent structures are related to late Scandian exhumation and extension and are characterized by a strong amphibolite-facies fabric with subhorizontal ENE-WSW fold axes and lineations and evidence for asymmetric top-to-west sinistral extensional shearing (Robinson 1995; Terry and Robinson 2003).

In the eastern part of the WGR, in the Trollheimen and surrounding areas, the Caledonian nappe pile includes from bottom to top the Åmotsdal, Risberget, Sætra, Båhø-Surna, and Støren Nappes (Krill 1980). The Åmotsdal quartzite represents the Lower Allochthon (fig. 1). The crystalline Risberget Nappe is dominated by augen gneiss dated to ca. 1650-1640 and 1190-1180 Ma (Handke et al. 1995; Robinson 1995). It is attributed to the Middle Allochthon and correlated with the Kvitvola Nappes in SE Norway and the Tännäs Nappe in Sweden (Claesson 1980; Lamminen et al. 2011). The Sætra Nappe consists of feldspathic sandstone and am- phibolites. It is interpreted to represent a Late Neoproterozoic arkose sequence intruded by dolerite dikes, and it is correlated with the Middle Allochthon Särv Nappe in Sweden, where both sandstones and crosscutting dikes are well preserved (Hollocher et al. 2007; Be'eri-Shlevin et al. 2011). The Blåhø-Surna Nappe is composed of garnet-mica schist and amphibolite and is thought to correlate with the Seve Nappes in Sweden. The Støren Nappe is primarily composed of Ordovician ophiolite and outboard arc fragments. It is characterized by lowgrade metamorphism and belongs to the Upper Allochthon Trondheim Nappe Complex.

The transition between the Western Gneiss Complex and the overlying nappe pile is complicated by two factors. (1) Late-thrust imbrication of basement and nappes during convergence resulted in juxtaposition of basement slices of seemingly similar composition and origin but of different metamorphic grade (Gee 1980; Robinson 1995; Robinson and Hollocher 2008a). In the Trollheimen area, a lower basement apparently lacking pods of eclogites and an upper basement hosting pods of eclogite are unambiguously identified, and they are separated by a thin layer of Neoproterozoic feldspathic quartzite (Gee 1980; Robinson 1995; Robinson and Hollocher 2008a). (2) Extensional deformation resulted in attenuation of the thickness of the nappes and infolding of nappes into the basement resulting in tight fold structures with WSW fold axes (Robinson 1995; Braathen et al. 2000). In the study area around Molde, two steep synforms are mapped (fig. 3), the Moldefjord synform in the north and the narrow Helleneset synform in the south, separated by the Rekdalshesten antiform (fig. 3). The limbs of the synforms expose examples of an extremely thinned tectonostratigraphic sequence, with rocks attributed to the Støren nappe in the core of the Moldefjord synform and basement rocks exposed in the antiforms. In the core of the Rekdalshesten antiform, a window of lower basement is exposed and separated from an upper basement by a layer of quartzite assigned to the Åmotsdal quartzite (fig. 3; Robinson 1995).

\section{Methods}

Thin sections of the samples were examined with optical microscopy and scanning electron microscopy (SEM; table 1). Special care was taken in order to find small eclogite-facies minerals, such as omphacite, phengite, or rutile, or pseudomorphs after these. Whole-rock geochemical data were obtained using a PANalytical Axios 4-kW x-ray fluorescence spectrometer at the Geological Survey of Norway. 


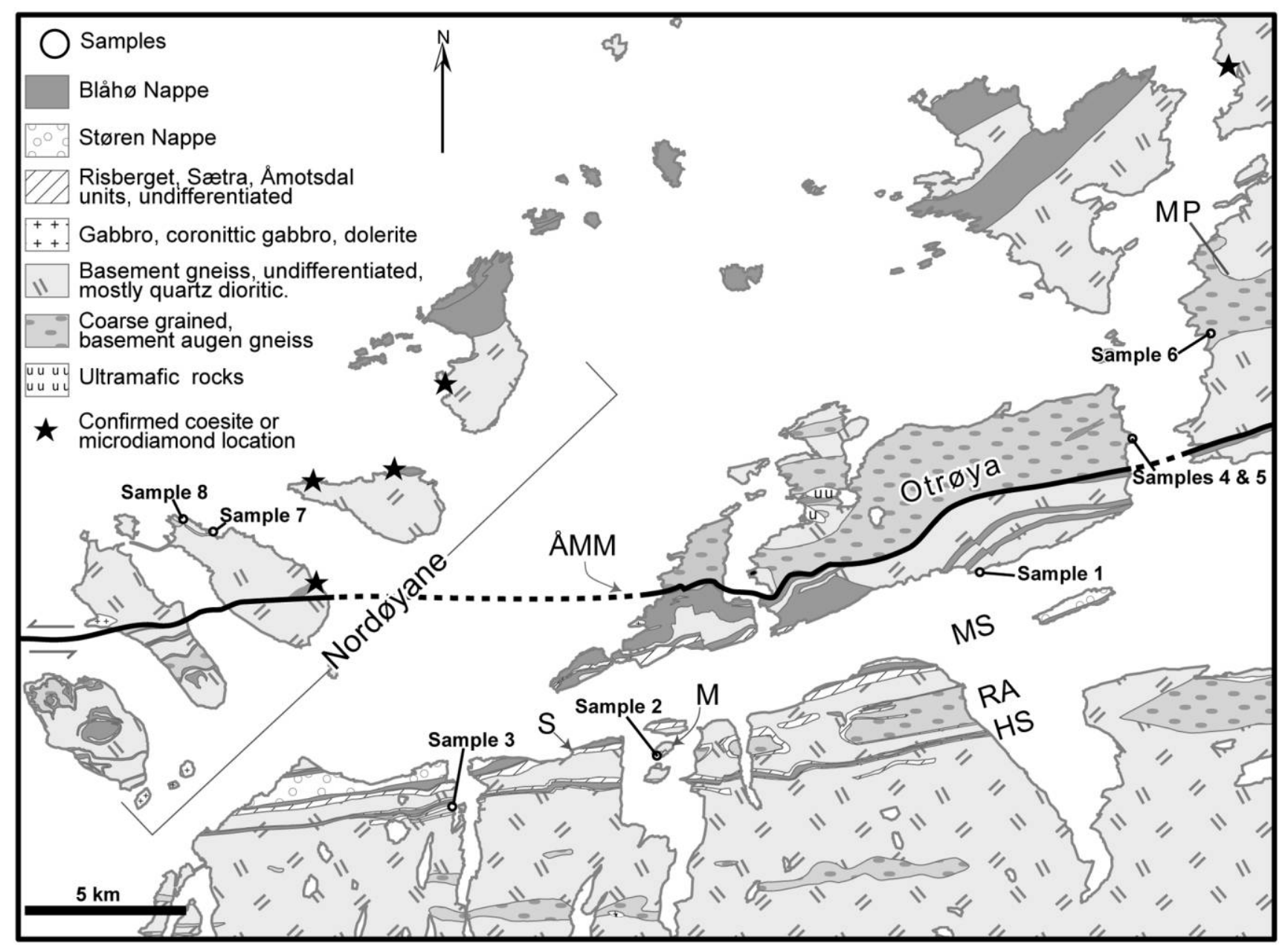

Figure 3. Geologic map of the study area showing the position of sampling sites. ÅMM: Åkre-Midsund mylonite; HS: Helleneset synform; M: Medøya; MP: Molde peninsula; MS: Moldefjord synform; RA: Rekdalshesten antiform; S: Skår.

Major elements were determined on fused glass beads prepared from ignited powders, with a sample to flux $\left(\mathrm{Li}_{2} \mathrm{~B}_{4} \mathrm{O}_{7}\right)$ ratio of $1: 7$. Trace elements were determined on pressed-powder tablets. Zircon was separated after crushing, and hand-picked crystals were mounted in epoxy and polished to approximately half-thickness. All crystals were imaged with a panchromatic cathodoluminescence $(\mathrm{CL}) \mathrm{de}$ tector in a variable-pressure SEM before U-Pb analytical work (table 1).

$\mathrm{U}-\mathrm{Pb}$ dating of zircon was performed using two analytical techniques, namely secondary ion mass spectrometry (SIMS; supplement 4, available in the online edition or from the Journal of Geology office) and laser ablation-inductively coupled plasma-mass spectrometry (LA-ICP-MS; supplement 3 , available in the online edition or from the Journal of Geology office). The SIMS analyses were conducted using the Cameca IMS 1280 at the NORDSIM laboratory, Swedish Museum of Natural History, in Stockholm (Whitehouse et al. 1999; Whitehouse and Kamber 2005). The LA-ICPMS analyses were done at the Geological Survey of Norway. A Finnigan ELEMENT1 single collector high-resolution sector ICP-MS was coupled to a UP193-FX 193-nm short-pulse excimer laser ablation system from New Wave Research. The raw data from both SIMS and ICP-MS were calibrated against the 91500 reference zircon with an age of $1065 \mathrm{Ma}$ (Wiedenbeck et al. 1995).

Electron backscatter diffraction (EBSD) data were collected on four zircon crystals selected after SIMS analysis. Analyses were undertaken on a Zeiss Evo housed at the Microstructural Analysis Facility of Curtin University, using an Oxford Instruments EBSD system and Channel 5 software. The EBSD 


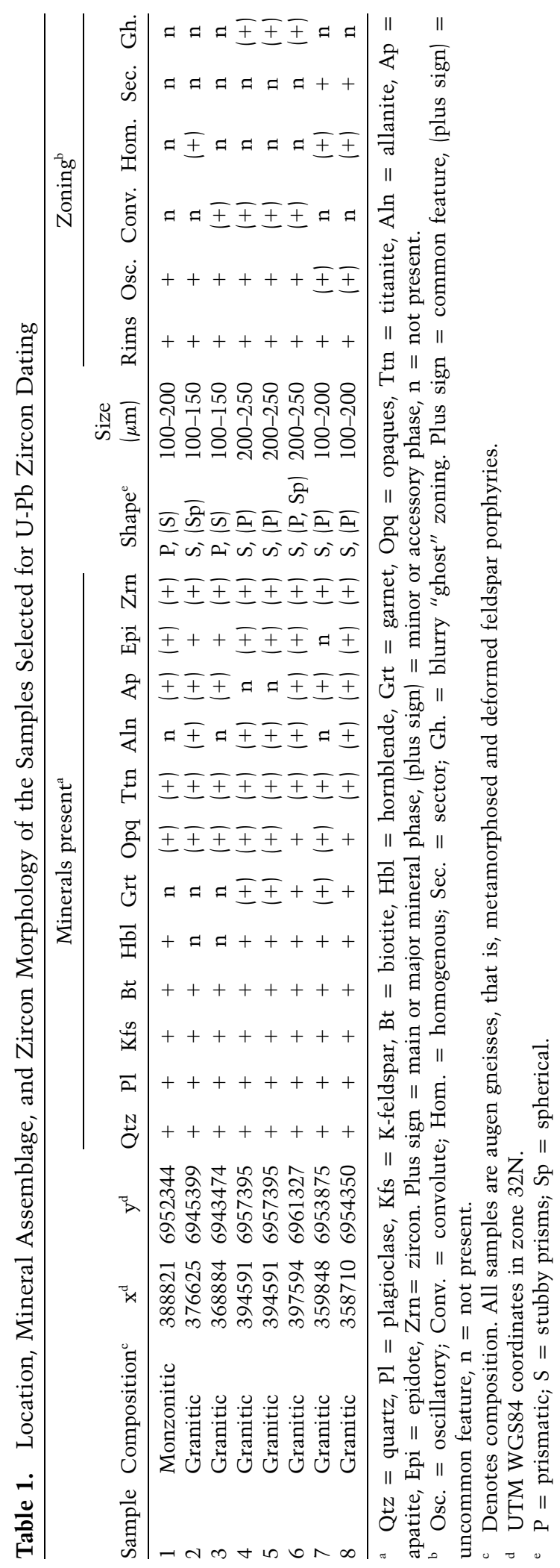


data were collected and processed following the procedures described in Reddy et al. $(2007,2008)$. A more thorough description of analytical methods is given in the appendix, available in the online edition or from the Journal of Geology office, and references therein.

\section{Results}

Eight samples of augen gneiss were selected from within a $35 \times 13-\mathrm{km}$ area in the northwestern part of the WGR, extending from Nordøyane in the west to the Molde peninsula in the east (fig. 3). In the study area, the Baltican Basement is both imbricated and infolded with nappes. Therefore, eclogitebearing basement (HP to UHP domains), eclogitefree basement, and rock units attributed to the nappes are closely associated in the field. Samples were selected from these three different settings (fig. 3). Samples 1 and 2 come from areas where evidence for eclogite formation is totally lacking. Sample 3 comes from a unit which is suspected to be allochthonous but where eclogite has been found in the adjacent basement gneiss. Samples 4, 5, 6, 7 , and 8 come from areas believed to have been subjected to UHP conditions.

The studied samples have granodioritic compositions, except for sample 1 , which is a quartz monzodiorite. Geochemically, they resemble previously studied granitoids in the region. They are comparatively $\mathrm{K}$ rich and yield compositions that are intermediate between peraluminous and metaluminous, and they show trace element signatures typical for a volcanic arc environment (fig. 4a, 4b). The only noteworthy variation concerns the concentration of $\mathrm{Zr}$, which in samples 4 and 6 is significantly higher than in the other samples and which suggests a signature transitional to A-type granitoid (fig. 4c). An A-type origin for these two samples agrees with the work of Carswell and Harvey (1985) on the very same augen gneiss units.

All sampled units have been affected by late Scandian amphibolite facies deformation and metamorphism, which has previously been dated by U$\mathrm{Pb}$ titanite data to ca. $395 \mathrm{Ma}$ (Tucker et al. 2004; Krogh et al. 2011; fig. 9). Age calculations are therefore performed by anchoring at a lower intercept of $395 \mathrm{Ma}$ whenever concordia ages are incalculable, including whenever the data distribution does not identify an episodic lead loss event (ICP-MS data from samples 1-3). The alternative would be to report the weighted average ${ }^{207} \mathrm{~Pb} /{ }^{206} \mathrm{~Pb}$ age, which for most samples is equivalent to the age yielded by forced regression. Such a procedure, however,
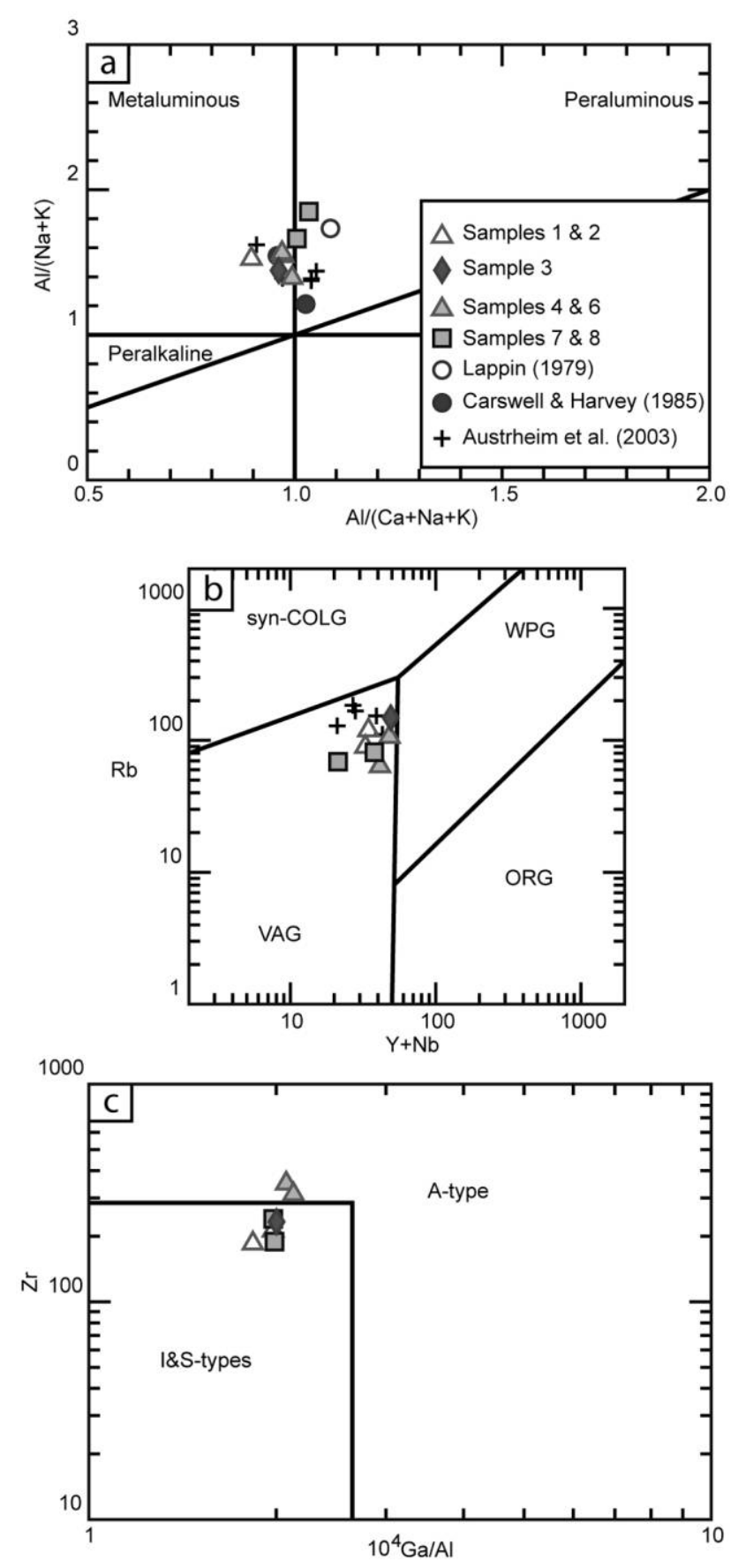

Figure 4. Petrogenetic discrimination diagrams after Maniar and Piccoli $(1989 ;$ a); Pearce et al. $(1984 ; b)$; Whalen et al. $(1987 ; c)$.

would imply that the zircon did not lose any lead during this amphibolite facies event, a possibility we consider unlikely. Brief descriptions of samples and their context are given below. Table 1 summarizes the petrography and zircon morphology, and supplement 2 , available in the online edition 

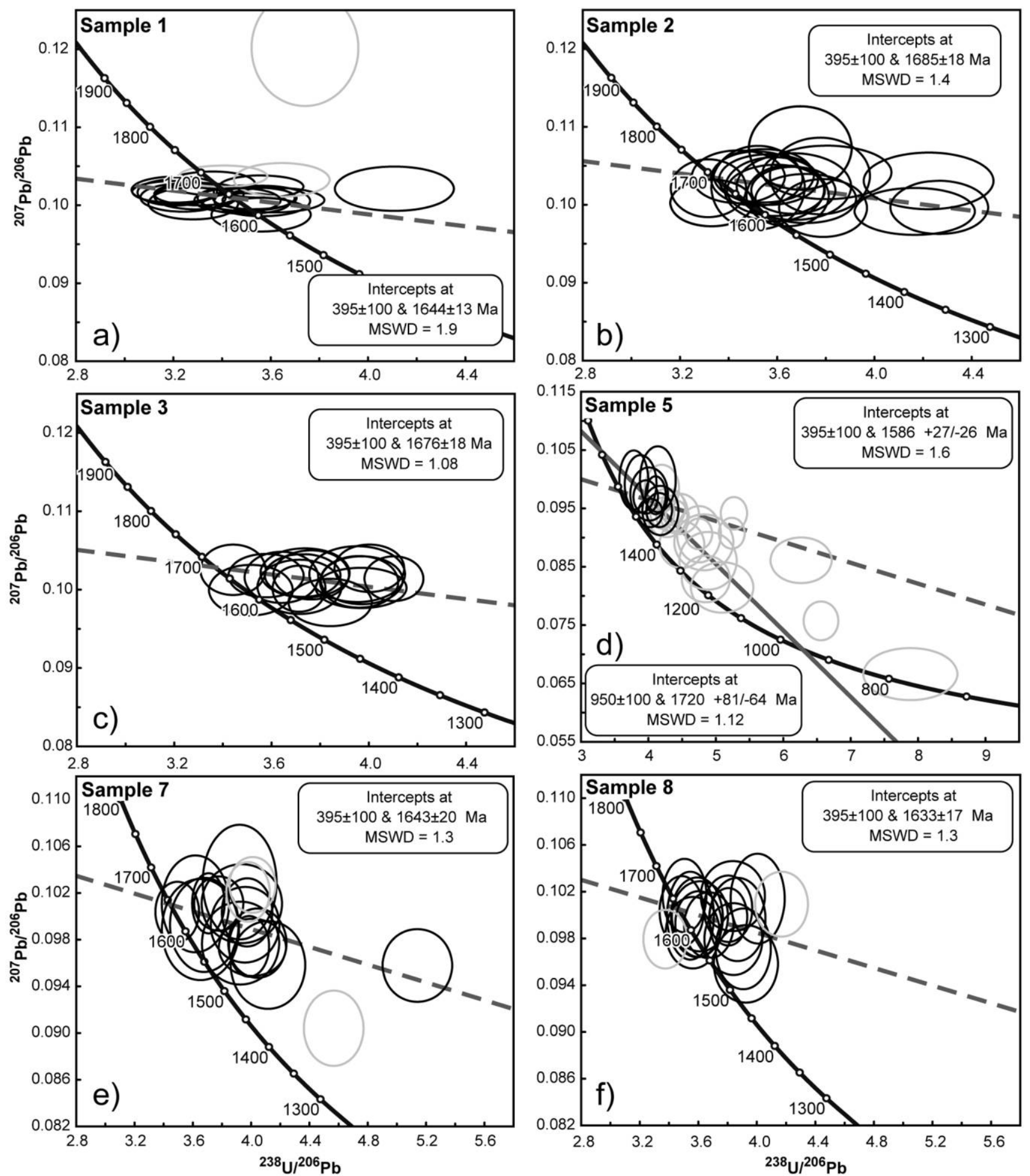

Figure 5. Terra-Wasserburg concordia diagrams showing the data acquired by LA-ICPMS. All reported errors are $2 \sigma$ and include decay constant errors. Monte Carlo-generated errors are given when error distributions are significantly nonsymmetric. 
or from the Journal of Geology office, lists the whole-rock chemistry. U-Pb data are presented in figures 5 and 6 and listed in supplements 3 and 4 .

Sample 1: PR412, Quartz Monzodioritic Porphyry. Mapping along the entire south coast of Otrøya west of Molde (P. Robinson, unpublished data) shows a narrow belt of distinctive, dark monzodioritic augen gneiss with small $(\sim 1-\mathrm{cm})$ intact $\mathrm{K}$ feldspar phenocrysts. It is very different from the adjacent pink layered basement gneiss and was considered as an intrusive body, though both units are parallel and share the pervasive late Scandian sinistral shear fabric. Eclogite is apparently lacking in
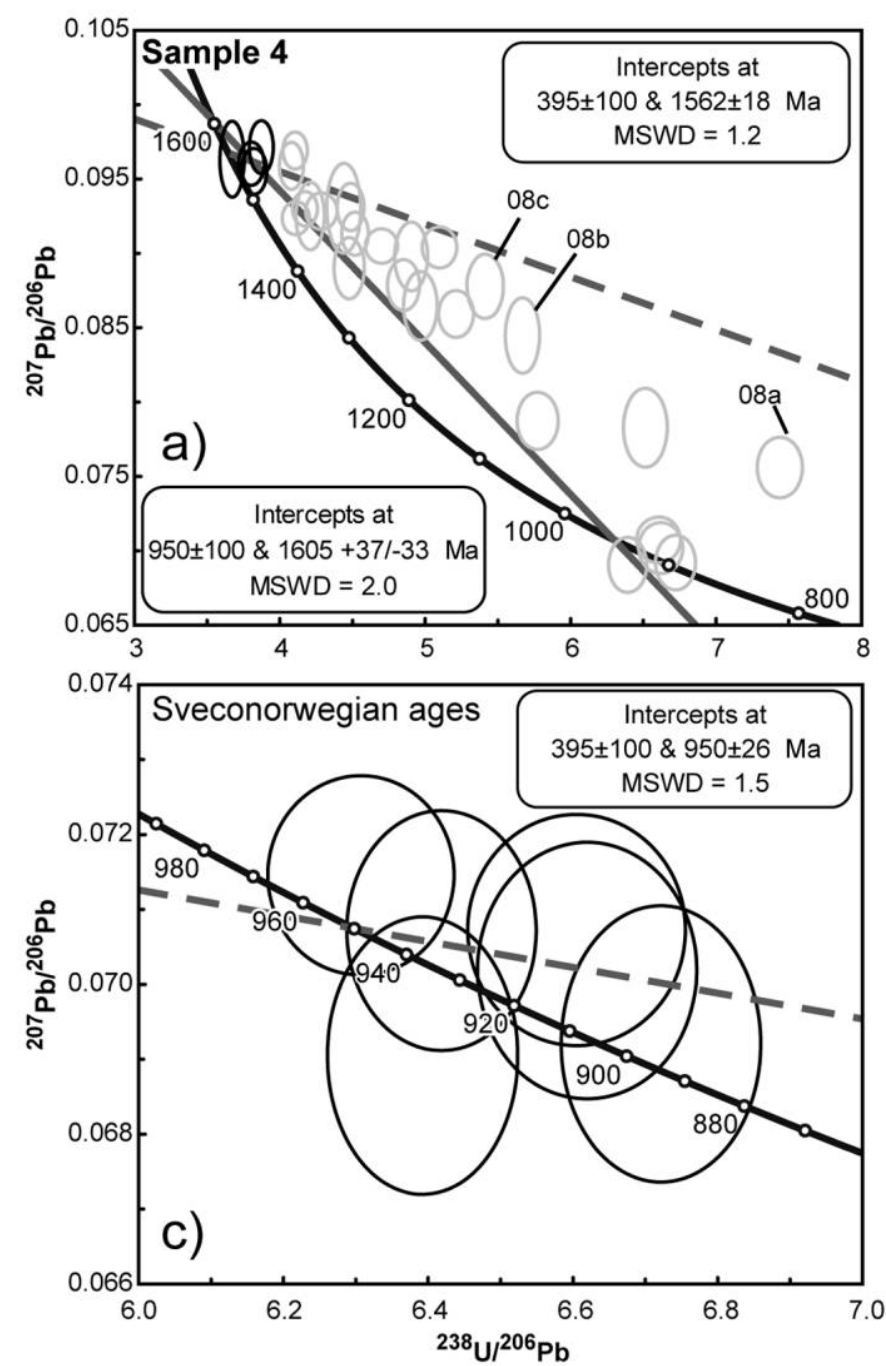

both the augen gneiss and the surrounding basement gneiss along this coast of Otrøya. Zircon crystals show oscillatory growth zoning and have thin, presumably metamorphic, CL-bright rims, too narrow to be analyzed separately. Twenty zircon grains were analyzed by LA-ICP-MS. One analysis was discarded due to a high common lead content, and regression from $395 \pm 100 \mathrm{Ma}$ through the remaining analyses revealed that the weighted residuals of two analyses are beyond $2 \sigma$ of the average, suggesting these are outliers. Regression from $395 \pm$ $100 \mathrm{Ma}$ through the remaining 17 data points yields an upper intercept age of $1644 \pm 13 \mathrm{Ma}$ (all re-
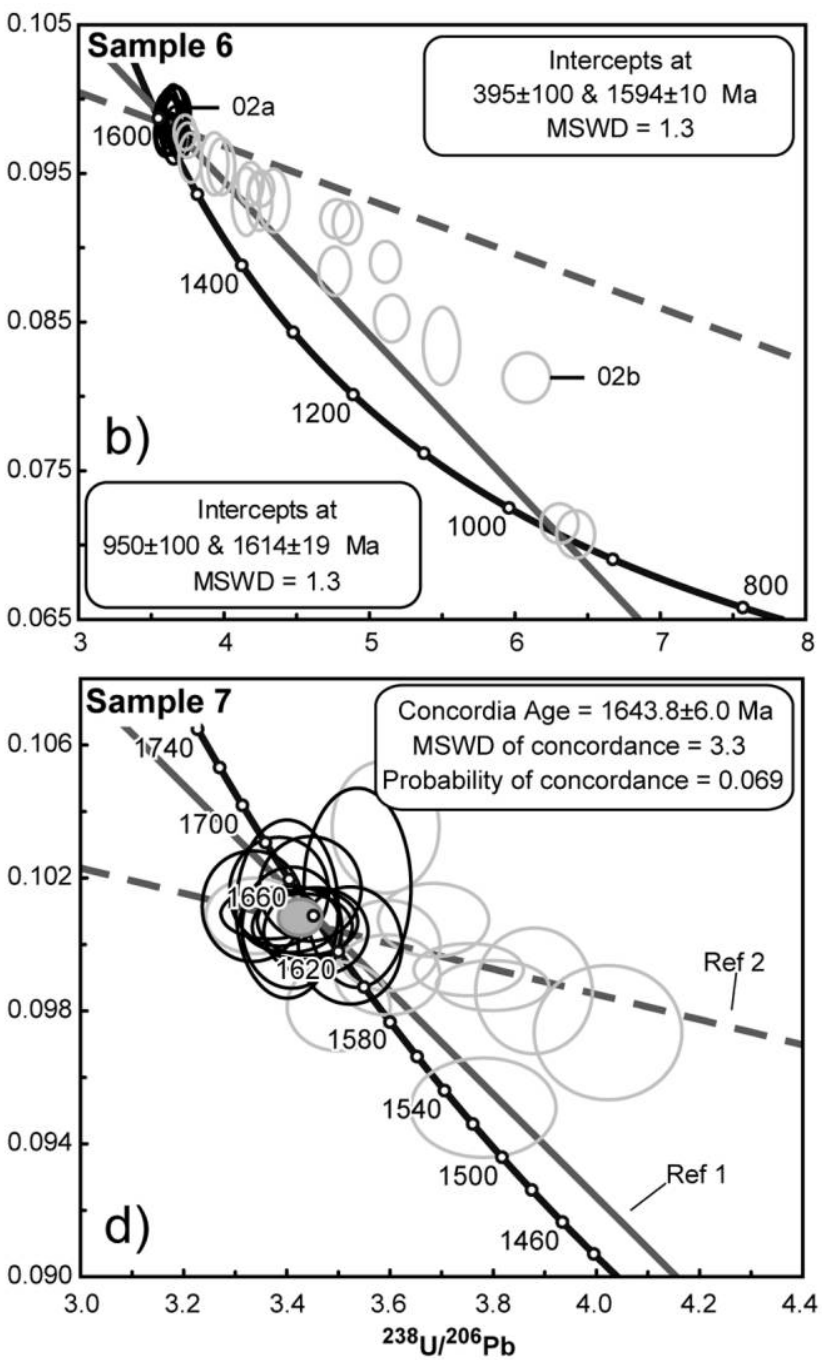

Figure 6. Terra-Wasserburg concordia diagrams showing the data acquired by SIMS. All reported errors are $2 \sigma$ and include decay constant errors. $a$, The three analyses for zircon 08 imaged in figure $8 I, 8 J$ are indicated (analyses in supplement 4, available in the online edition or from the Journal of Geology office); $b$, the two analyses for zircon 02 imaged in fig. $8 E, 8 F$ are indicated; $c$, pooled data for samples 4 and 6 ; $d$, Ref1: reference line anchored at 1643 and $1255 \mathrm{Ma}$, the latter corresponding to the age of the Flem Gabbro; Ref2: reference line anchored at $395 \mathrm{Ma}$ to show the effect of Caledonian lead loss. 
ported errors are $2 \sigma$; MSWD $=1.9$; fig. $5 a$ ), which is interpreted as the age of magmatic crystallization. This is within error of the weighted average of ${ }^{207} \mathrm{~Pb} /{ }^{206} \mathrm{~Pb}$ ages at $1648 \pm 8 \mathrm{Ma}$ (MSWD $=1.7$ ).

Sample 2: PR866, Granodioritic Augen Gneiss. To the south of Moldefiord on the island of Medøya (fig. 3), a window of lower basement lacking eclogite bodies is exposed in the core of the Rekdalshesten antiform. It is separated from an upper basement containing eclogites by a layer of quartzite (interpreted as Åmotsdal quartzite; fig. 3). The base of the upper basement is interpreted as a western extension of the Storli Thrust of Trollheimen. A specimen of dark, highly deformed porphyry was selected a few meters below the quartzite. The zircon crystals are prismatic to rounded. They show oscillatory growth zoning and have a narrow CLbright rim, too narrow to be analyzed separately. Twenty oscillatory-zoned zircon grains were analyzed using LA-ICP-MS, resulting in 20 relatively well-clustered data. Regression from $395 \pm 100 \mathrm{Ma}$ through these data points yields an upper intercept age of $1685 \pm 18 \mathrm{Ma}(\mathrm{MSWD}=1.4$; fig. $5 b)$, whereas the weighted average of ${ }^{207} \mathrm{~Pb} /{ }^{206} \mathrm{~Pb}$ ages yields an age of $1659 \pm 14 \mathrm{Ma}$ (MSWD $=1.2$ ). The range $1685 \pm 18 \mathrm{Ma}$ is interpreted as the most likely age of magmatic crystallization.

Sample 3: PR-D, Granodioritic Augen Gneiss. Two layers $(<200 \mathrm{~m})$ of porphyritic felsic gneiss are located on the south limb of the extremely narrow Helleneset Synform in Brattvåg (fig. 3). They are distinct from the normal "stripey" basement gneiss in the vicinity which hosts eclogite pods. They were tentatively interpreted as narrow synclinal infolds of the Risberget Nappe within basement (Robinson 1995; Robinson and Hollocher 2008b). It was speculated that these rocks have the same age of ca. $1190 \mathrm{Ma}$ as the dated upper member of the Risberget Augen Gneiss in the Moldefjord Synform at Skår (some $5 \mathrm{~km}$ to the northeast of Brattvåg; Handke et al. 1995). However, it is known that the Risberget Nappe elsewhere also contains augen gneisses with a ca. 1650-1640 Ma protolith age (Handke et al. 1995).

Zircon grains are stubby to prismatic, and they have a dark CL core and bright CL rims. The cores commonly display oscillatory growth zoning, but some grains also show convolute or wavy zoning. The rims are typically featureless or show a diffuse convolute zoning. Sixteen LA-ICP-MS analyses targeted 16 zircon cores. Regression of the data through $395 \pm 100 \mathrm{Ma}$ record an upper intercept age of $1676 \pm 18 \mathrm{Ma}$ (MSWD = 1.08; fig. $5 c$ ) which is interpreted as the age of magmatic crystallization of the rock. The weighted average of ${ }^{207} \mathrm{~Pb} /{ }^{206} \mathrm{~Pb}$ ages is $1646 \pm 11 \mathrm{Ma}$ (MSWD $=0.83$ ). For some analyses, the laser beam may have unavoidably sampled partly material of the rim. This would explain some of the spread of analyses along the discordia line (e.g., analyses 4, 6, 7, and 9).

Samples 4, 5: PR-944x and PR-944y, Granodioritic Augen Gneiss. Samples 4 and 5 are granitic augen gneisses that were sampled from an exposure along the northeastern coast of Otrøy. Sample 4 has a horizontal lineation that is characteristic of the amphibolite-facies late Scandian extensional fabric that dominates the region. Sample 5 was collected because it contains a nonfoliated felsic leucosome with coarse hornblende. This leucosome crosscuts the late Scandian fabric and thus appears to have formed by partial melting during very late stages of Scandian ductile extension. Roughly $100 \mathrm{~m}$ away from the sampling locality (and within the same type of augen gneiss) is a 3-4-m retrograded zoisite eclogite boudin confirming that the rocks have been subjected to HP, or even probably UHP conditions.

The zircons from these samples are typically stubby prisms. They have a core with oscillatory (fig. 8M, 8N) or convolute (fig. 8I) zoning and variably thick, poorly zoned rims that appear bright in CL (fig. $8 M, 8 N$ ). Some of these rims bulge into the core (fig. 8M). Twenty-nine SIMS analyses of core and rim in 15 grains from sample 4 yielded data that show a great deal of scatter. Rather than forming a well-defined discordia line, the data

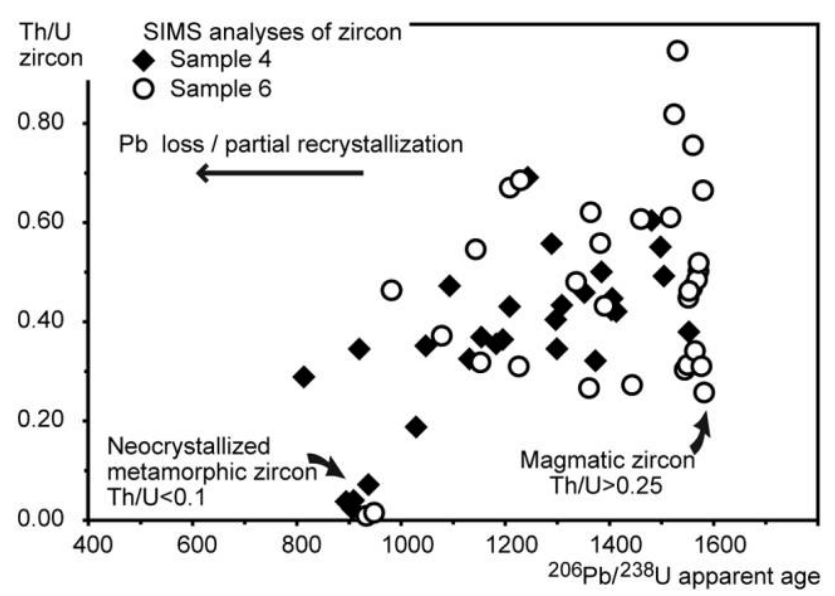

Figure 7. Zircon $\mathrm{Th} / \mathrm{U}$ ratio versus apparent ${ }^{206} \mathrm{~Pb} /{ }^{238} \mathrm{U}$ age of secondary ion mass spectrometry analyses from augen gneiss samples 6 and 4 from the Nordøyane UHP domain. The figure shows the contrast between the low $\mathrm{Th} / \mathrm{U}(<0.07)$ neocrystallized Sveconorwegian metamorphic zircon (ca. $950 \mathrm{Ma}$ ) and the magmatic zircon (Th/ $\mathrm{U}>0.25,1617-1593 \mathrm{Ma}$ ) partially recrystallized during the Sveconorwegian and Scandian orogenies. 
points define a fan in an inverse concordia diagram with an origin around $1600 \mathrm{Ma}$ and two enveloping lines with lower intercepts at around 930 and 400 Ma (fig. 6a). Additionally, two weakly zoned grains yield nearly concordant analyses with ${ }^{207} \mathrm{~Pb} /{ }^{206} \mathrm{~Pb}$ ages ranging from $894 \pm 7$ to $937 \pm 7 \mathrm{Ma}$ (zircons 02 and 04; supplement 4; figs. $6 a, 8 L)$. Attempting to calculate a concordia age from any of these data points was unsuccessful, but forced regression of the four oldest and most concordant data points through probable Caledonian (395 Ma) and Sveconorwegian (950 Ma) ages resulted in two upper intercept ages at $1562 \pm 18$ and $1605+37 /-33 \mathrm{Ma}$, respectively, representing minimum and maximum ages of crystallization of the magmatic protolith.

Twenty-eight LA-ICP-MS analyses of 28 grains from sample 5 plotted in the same manner as the data from sample 4. This sample was selected in order to date the partial melting event, which should be late Scandian (ca. 400-380 Ma) based on the crosscutting field relationships. However, as seen from figure $5 d$, the partial melting does not appear to have generated any new zircon growth, except for a thin rim observed at the margin of some crystals that were too thin to be analyzed separately. Confining the age for this sample proved very challenging, but in view of the similarity of data distribution, it can be assumed that this sample records the same events as sample 4, namely, a crystallization age between 1605 and $1562 \mathrm{Ma}$ and partial resetting during Sveconorwegian and Caledonian metamorphism.

The EBSD data were collected in one selected zircon of sample 4 with a step of $3 \mu \mathrm{m}$ (zircon 08; supplement 4; fig. 8J). As shown in the CL image (fig. 8I), this zircon is characterized by three zones: (1) a core with oscillatory to convolute zoning; (2) an inner, moderately luminescent rim; and (3) an external luminescent rim. The EBSD orientation map shows a cumulative lattice misorientation of $5^{\circ}$ across the crystal and also shows several discrete boundaries corresponding to low-angle misorientation steps not exceeding $2^{\circ}$ (boundaries in red in fig. 8J). One of these boundaries corresponds to a prominent ca. $5-\mu \mathrm{m}$-thick discontinuity in the $\mathrm{CL}$ image across the entire crystal, which is filled with luminescent zircon. Another corresponds to a set of dark linear features in the CL image (arrow in fig. 8I, 8J), which also intersect the main zones in the crystal. Three SIMS U-Pb analyses, performed in each of these zones (figs. 6a, 8I, 8J), show similar moderate $U(87-173 \mathrm{ppm})$ and Th (30-82 ppm) contents and are significantly discordant $(-21.3 \%$ to $-26.6 \%)$, pointing to a combination of Sveconor- wegian and Caledonian resetting. The most discordant of these analyses (analysis 08a; supplement 4; figs. $6 a, 8 I, 8 J)$, were partly made on the dark linear features in the CL image and associated lowangle boundary in the EBSD image (arrow in fig. 8I, $8 J)$.

Sample 6: PR-A, Granodioritic Augen Gneiss. This granitic augen gneiss was sampled from a large roadcut at the western end of the Molde Peninsula. The objective was to test the model age of ca. 1508 Ma derived by Tucker et al. (1990) from the same outcrop (their sample 16-RT87-5). Nearly all of this exposure is augen gneiss with a late Scandian subhorizontal lineation of the feldspar augen. The sample was selected as showing the best preservation of the outlines of former K-feldspar phenocrysts.

Zircon crystals have a core with simple oscillatory growth zoning (fig. $8 E, 8 G$ ) or alternatively with convolute or sector zoning (fig. $8 \mathrm{C}, 8 \mathrm{H}$ ). Convolute zoning can be very complex or very bright in CL (fig. 8H). Two sets of rims are observed: (i) relatively thick rims that appear dark in CL (fig. $8 A, 8 C$ ), mantled by (ii) narrow rims that appear bright in CL (fig. 8E). Thirty-two SIMS analyses in a variety of zones in 19 grains scatter in a similar fan shape as for sample 4, and computing well-defined intercept ages using all the data is not possible (fig. 6a). Hence, the 15 oldest and most concordant data points were selected. Forced regression of these data through 395 and 950 Ma yield upper intercept ages of $1593 \pm 10$ and $1617 \pm 19 \mathrm{Ma}$, respectively. The intrusion age of the porphyritic granite can be estimated to lie within these two dates and can be quoted as $1617+19 /-34 \mathrm{Ma}$. This age bracket overlaps the bracket obtained for sample 4. Two distinct, dark CL rim textures yield concordant SIMS analyses with ${ }^{207} \mathrm{~Pb} /{ }^{206} \mathrm{~Pb}$ ages of $953 \pm 34$ and $943 \pm 38 \mathrm{Ma}$ (zircons 09 and 14; supplement 4; fig. $8 A$ ), documenting a Sveconorwegian overprint.

The EBSD data were collected from three zircon crystals in sample 6 (zircons 02, 06, 14) with a step of $2 \mu \mathrm{m}$ (fig. 8). Zircon 02, following the CL image (fig. $8 E$ ), is an oscillatory-zoned (magmatic) prism capped by a thin luminescent (metamorphic) rim. The prism is characterized by a gradual fading of the oscillatory growth zoning in the lower half of the crystal section (fig. 8E). The EBSD orientation image shows a cumulative lattice misorientation of $8^{\circ}$ across the crystal increasing progressively in the lower part of the crystal section (fig. 8F). One low-angle boundary in the lower right corner of the section matches a dark linear feature on the CL image (fig. 8E, 8F). Two SIMS analyses were collected in this crystal (figs. 6b, 8E, 8F), and both 

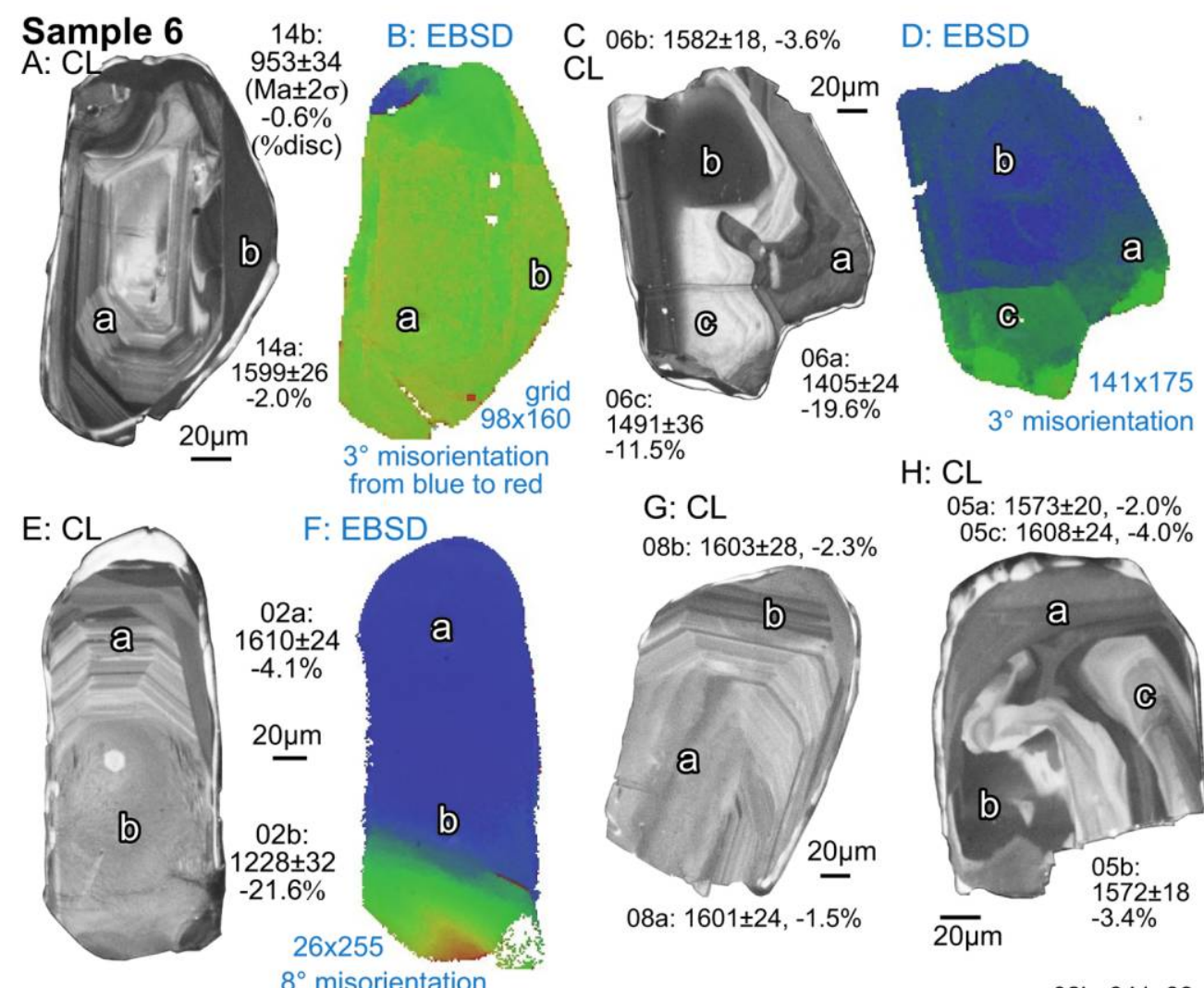

Sample 4

$8^{\circ}$ misorientation

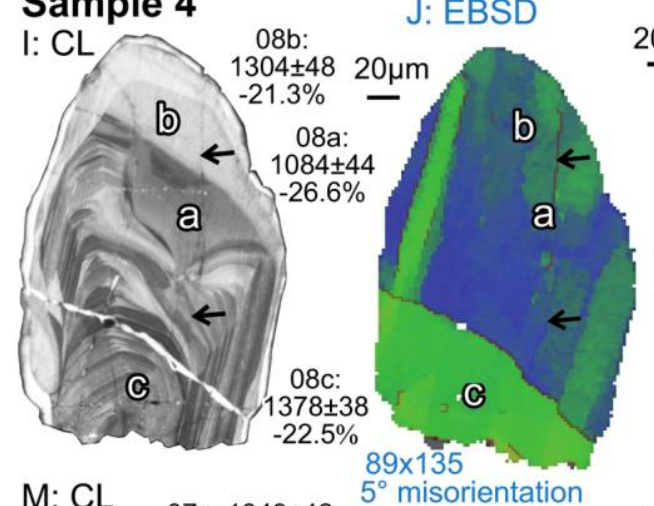

$\mathrm{G}: \mathrm{CL}$

08b: $1603 \pm 28,-2.3 \%$

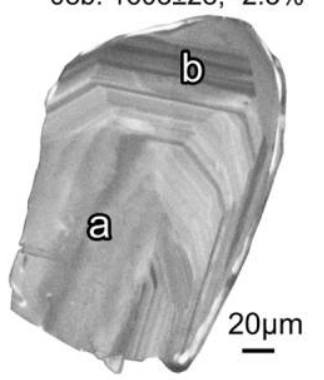

08a: $1601 \pm 24,-1.5 \%$

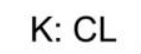

20um

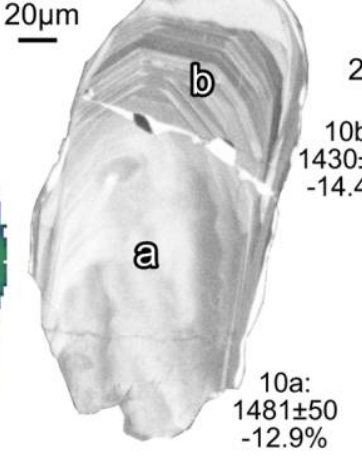

$\mathrm{H}: \mathrm{CL}$

05a: $1573 \pm 20,-2.0 \%$ $05 \mathrm{c}: 1608 \pm 24,-4.0 \%$

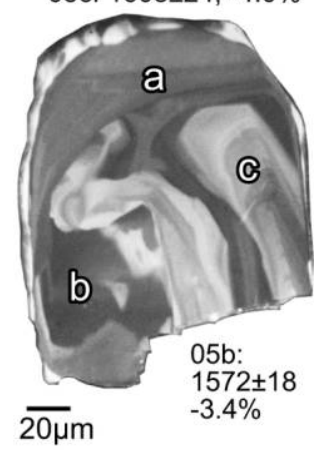

$\mathrm{L}: \mathrm{CL} \quad 02 \mathrm{~b}: 941 \pm 38$
$\mathrm{M}: \mathrm{CL}$

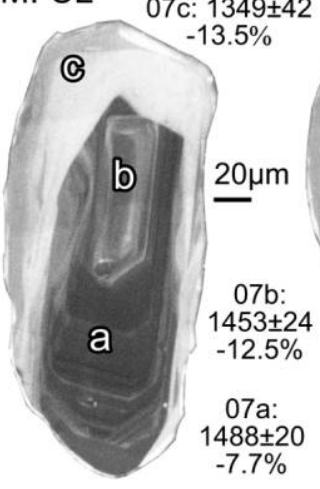

$\mathrm{N}: \mathrm{CL}$

B $1554 \pm 40$

$-0.1 \%$

Sample 7

O: CL
a20b:
$1689 \pm 28$
$-7.0 \%$

$\mathrm{P}: \mathrm{CL}$

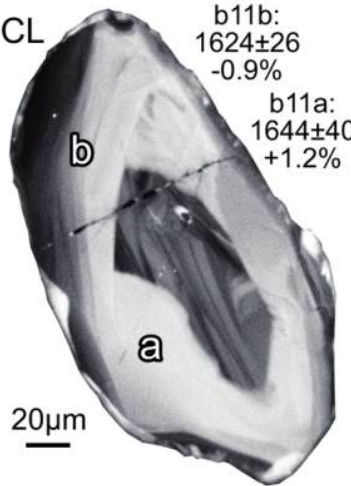


show similar U (151-165 ppm) and Th (68-77 ppm) concentrations. The first analysis, made within the oscillatory zoned upper part of the crystal $(02 a)$, is marginally discordant $(-4.1 \%)$ and plots close to the upper intercept ages of $1593 \pm 10$ and $1617 \pm 19 \mathrm{Ma}$. The other analysis, which was made within the seemingly unzoned lower part of the crystal is significantly discordant $(-21.6 \%)$. Disappearance of oscillatory zoning, misorientation of the lattice, and U-Pb discordance are thus correlated in this crystal. Zircon 06 shows a core characterized by convolute zoning, partially surrounded by a relatively thick nonluminescent rim (fig. 8C). The EBSD image shows little cumulative lattice misorientation $\left(3^{\circ}\right)$, with one clear orientation boundary crossing the core. This boundary corresponds to two dark lines in the CL image that intersect at an angle of ca. $120^{\circ}$. Three SIMS analyses in the core and rim of this crystal are variably discordant $(-3.6 \%$ to $-19.6 \%)$. Zircon 14 is characterized by a prismatic oscillatory zoned core dated by one near-concordant SIMS analysis at $1599 \pm$ $26 \mathrm{Ma}\left({ }^{207} \mathrm{~Pb} /{ }^{206} \mathrm{~Pb}\right.$ age; fig. $\left.8 \mathrm{~A}\right)$, partially surrounded by a Sveconorwegian metamorphic rim yielding a concordant SIMS age at $953 \pm 34 \mathrm{Ma}$. The EBSD data indicate some cumulative lattice misorientation of $3^{\circ}$, mainly located along a short discrete boundary hosting an inclusion (fig. 8B). The important information that can be read from this EBSD image is that no significant misorientation is detected between the Sveconorwegian rim and the magmatic core of the crystal.

The intrusion age of ca. $1508 \mathrm{Ma}$ proposed by Tucker et al. (1990) for this outcrop (their sample 16-RT87-5), is derived from a single U-Pb TIMS analysis of abraded zircon projected from a lower intercept at $395 \mathrm{Ma}$. In view of the fan-shape distribution of zircon $\mathrm{U}-\mathrm{Pb}$ analyses obtained in this study from samples 4, 5, and 6, it can be concluded that the model age of $1508 \mathrm{Ma}$ is incorrect. Also, samples 4, 5, and 6 are from a suite of augen gneisses that were dated by Carswell and Harvey (1985) using the Rb-Sr method. A 19-point whole- rock $\mathrm{Rb}$-Sr errorchron $(\mathrm{MSWD}=14.8$ ) with initial ratio at 0.7035 was interpreted to record intrusion at $1506 \pm 22 \mathrm{Ma}$. This age should also be abandoned.

Samples 7, 8: PR-B and PR-C, Granodioritic Augen and Pencil Gneisses. Terry et al. (2000a), Terry and Robinson (2004), and Krogh et al. (2011) showed a detailed map of the northern coast of Flemsøya with contact relations for the $1255 \pm 2$ Ma Flem Gabbro, various eclogite bodies, and the Kvalvika garnet peridotite-pyroxenite. At its eastern contact, the Flem Gabbro is chilled against an augen gneiss, represented by sample 7 , and both rocks contain evidence of a near vertical eclogite-facies strain fabric. The surrounding gneisses have a strong late Scandian subhorizontal stretching lineation. Some of these are porphyries in which the K-feldspar phenocrysts are extremely elongated horizontally to create a pencil gneiss. Sample 8 is of this pencil gneiss. The purpose of this sampling was to confirm that the rocks mapped in this special location belong to the same augen orthogneiss so widely mapped elsewhere in the UHP metamorphic zone.

These samples contain stubby prismatic to rounded zircon crystals. A core with oscillatory or convoluted zoning is typically surrounded by a variably thick luminescent rim, commonly convex toward the core (fig. 8O, 8P). For some crystals, the rim seems to largely replace the core (fig. $8 P$ ). Twenty-three SIMS analyses in core and rims of 17 grains were made from sample 7 and 18 LA-ICPMS analyses were made from sample 8 (figs. $5 e, 5 f$, $6 d)$. The data from both samples show a fair amount of scatter but not so much as shown by samples 6 and 4. However, a similar fan-like distribution of analyses is clearly observed in the concordia plot of sample 7 .

Twelve analyses of sample 7 define a concordia age of $1644 \pm 6 \mathrm{Ma}$, whereas most of remaining analyses point toward a Caledonian lower intercept. One or possibly two data points appear to signal a pre-Caledonian thermal event. This event could be the intrusion of the $1255 \mathrm{Ma}$ Flem Gabbro

Figure 8. Selected cathodoluminescence (CL) images of dated zircons for samples 4, 6, and 7 from the UHP domain and electron backscatter diffraction (EBSD) cumulative orientation maps for four of these crystals. The EBSD orientation maps show up to $8^{\circ}$ misorientation from a reference point in the blue area to the red area. Discrete boundaries corresponding to local misorientation steps are indicated by red lines. The cumulative misorientation is indicated for each crystal as well as the size of the grid of acquisition of EBSD data. The locations of secondary ion mass spectrometry (SIMS) analyses are indicated by labels (analyses in supplement 4, available in the online edition or from the Journal of Geology office). The ${ }^{207} \mathrm{~Pb} /{ }^{206} \mathrm{~Pb} \pm 2 \sigma$ age in $\mathrm{Ma}$ and the discordance in percentages are indicated for each analysis. The size of the SIMS primary beam is in the $15-20-\mu \mathrm{m}$ range, approximately corresponding to the size of the label letter in the image. The interpretation of images is discussed in the text. The black arrows point to a dark linear feature in the CL image matching a low-angle boundary in the EBSD map. 
as indicated by the reference line in figure $6 d$, or it could be related to the presumably more regional event at ca. $950 \mathrm{Ma}$, indicated by metamorphic zircon in samples 6 and 4 . Forced regression of the data from sample 8 through 395 Ma yields an age of $1633 \pm 17 \mathrm{Ma}$, which is within uncertainty of the age yielded by sample 7 . It is therefore suggested that the two samples are from the same unit, despite showing very different textures. The tight clustering of data for sample 8 is remarkable in view of the extreme deformation state of this rock. By comparison, only one analyzed grain in sample 7 shows clear signs of lead loss during a Sveconorwegian or older event, and there is some probability that such grains are also present in sample 8 but that these have not been detected.

\section{Discussion}

Proterozoic Magmatism in the WGR. Some 50 zircon $\mathrm{U}-\mathrm{Pb}$ ages derived from outcrop samples are available to constrain the Proterozoic magmatic history of the WGR (Tucker et al. 1987, 1990, 2004; Skår et al. 1994; Austrheim et al. 2003; Skår and Pedersen 2003; Røhr et al. 2004; Krogh et al. 2011; this article). In the northwestern part of the WGR, late-Caledonian deformation is so intense that preCaledonian structural relations are generally transposed. Consequently, extensive sampling would be required to obtain a representation of minor rock types intruding this crust. In one of the few tectonic lenses in the Molde area that apparently escaped most of this deformation, a dolerite dike dated to $1251 \pm 3 \mathrm{Ma}$ is shown to crosscut a weakly deformed concentrically zoned granite-monzodiorite plutonic complex dated to $1654 \pm 1 \mathrm{Ma}$ (Austrheim et al. 2003). In the northwestern HP to UHP domains, 19 samples suggest that the bulk of the Baltican Basement formed during a single and short-lived magmatic interval between $1686 \pm 2$ and $1633 \pm 17 \mathrm{Ma}$. Augen gneiss samples 7 and 8 collected from the eclogite-bearing basement in the Nordøyane UHP domain, provide intrusion ages of $1644 \pm 6$ and $1632 \pm 21 \mathrm{Ma}$, well within this interval. Augen gneiss samples 6, 4, and 5 were collected from two nearby and probably related rock units near Molde, and are also from within the Nordøyane UHP domain (fig. 3). They provide new evidence for a significantly younger intrusive event between $1614 \pm 19$ and $1594 \pm 10 \mathrm{Ma}$, tailing the main 1686-1633 Ma magmatic event. Two gabbro bodies partly transformed to eclogite and hosted in the orthogneisses have crystallization ages at $1466 \pm 2$ and $1255 \pm 2 \mathrm{Ma}$ (Krogh et al. 2011), clearly indicating that gabbro and dolerite boudins represent intrusive bodies of Mesoproterozoic age.

The southeastern eclogite-free lower Baltican Basement has an age structure entirely similar to the eclogite-bearing Baltican Basement. Eleven orthogneisses have an intrusion age ranging from $1678 \pm 30$ to $1633 \pm 8 \mathrm{Ma}$ (Tucker et al. 1987, 1990; Skår and Pedersen 2003). These include augen gneiss samples 1 and 2 from the Molde area (fig. 5a, 5b) recording magmatic crystallization at $1685 \pm 18$ and $1644 \pm 13 \mathrm{Ma}$. One gabbro body in this basement has an age of $1461 \pm 2 \mathrm{Ma}$ (Selsnes coronitic metagabbro; Tucker et al. 2004). The interpretation that the Baltican Basement is progressively younger toward the south and west (Skarr 2000; Skår and Pedersen 2003) or, alternatively, younger from the eclogite-bearing domain toward the eclogite-free domain is not confirmed by the new data. The maximum ages for samples 6 and 4 at ca. 1614 and $1604 \mathrm{Ma}$, respectively, from the northern eclogite-bearing domain of the WGR, contradict this interpretation.

Sveconorwegian Overprint; Zircon Neocrystallization. Based on $\mathrm{U}-\mathrm{Pb}$ dating of zircon and titanite, Tucker et al. (1990) uncovered Sveconorwegian magmatic rocks southwest of the Romsdalen valley (fig. 2), prompting them to place a conceptual boundary along this valley dubbed the "approximate Sveconorwegian boundary." This boundary trends northwest, cutting perpendicularly across Caledonian structures. It does not correspond to any known structure in outcrop, so its physical expression is elusive.

The evidence for Sveconorwegian magmatism southwest of this boundary includes felsic plutons and dikes. Two granite plutons, including the voluminous Jølster pluton, are dated at $976 \pm 8$ and $966 \pm 3 \mathrm{Ma}$ (Corfu 1980; Skår and Pedersen 2003), and 4-m-wide granodioritic to pegmatitic dikes are dated between $971 \pm 5$ and $942+5 /-3 \mathrm{Ma}$ (Tucker et al. 1990; Skår and Pedersen 2003). These dikes are shown to cut a gneiss fabric or migmatitic layering and consequently provide direct evidence for deformation older than ca. $950 \mathrm{Ma}$ under amphibolite-facies conditions (Tucker et al. 1990). To support this interpretation, titanite U-Pb analyses from some 28 localities of variably gneissic rocks to the southwest of the Sveconorwegian boundary scatter between ca. 973 and $395 \mathrm{Ma}$, with a prominent concordant cluster in the interval between ca. 973 and $952 \mathrm{Ma}$ (fig. 9; Tucker et al. 1990; Skår and Pedersen 2003; Kylander-Clark et al. 2008). The concordant analyses point to a Sveconorwegian (neo)crystallization or resetting of titanite between ca. 973 and $952 \mathrm{Ma}$. For example, amphib- 
olite-facies migmatites along the Sognefjord transect in the southern eclogite-free part of the WGR yield titanite ages between $973 \pm 3$ and $961 \pm 4$ $\mathrm{Ma}$, overlapping with a zircon lower intercept age at $969 \pm 8 \mathrm{Ma}$ (Skår and Pedersen 2003). Also, a locality some $15 \mathrm{~km}$ southwest of the Sveconorwegian boundary (Vågåmo) yield both a titanite U$\mathrm{Pb}$ age at $961 \pm 2 \mathrm{Ma}$ and a garnet-whole-rock Sm$\mathrm{Nd}$ date at $922 \pm 1 \mathrm{Ma}$ (Kylander-Clark et al. 2008; Peterman et al. 2009).

Unambiguous evidence for Sveconorwegian granulite-facies metamorphism $\left(815^{\circ}-845^{\circ} \mathrm{C}\right.$ at around $1 \mathrm{GPa}$ ) is locally reported in the western part of the WGR in the HP to UHP (eclogite-bearing) Baltican Basement (Engvik et al. 2000; Wain et al. 2001; Røhr et al. 2004). Granulite-facies metamorphism is dated by means of two zircon dates at $987 \pm 10$ and $955 \pm 3 \mathrm{Ma}$ and one monazite date at $949 \pm 3 \mathrm{Ma}$ (Røhr et al. 2004; Glodny et al. 2008).

The argument for the absence of a Sveconorwegian overprint to the northeast of the approximate Sveconorwegian boundary is provided by titanite $\mathrm{U}-\mathrm{Pb}$ data. Titanite analyses from 47 localities, mainly of orthogneiss, from an area of roughly 8000 $\mathrm{km}^{2}$ to the northeast of the Romsdalen valley (Tucker et al. 1990, 2004; Kylander-Clark et al. 2008) all plot relatively tightly along a discordia line, defining lower and upper intercept ages of $395 \pm 3$ and $1657 \pm 3 \mathrm{Ma}$, respectively (Tucker et al. 2004; fig. 9). The lower intercept is interpreted as the age of late Scandian amphibolite-facies overprint, whereas the upper intercept records the magmatic crystallization of the protoliths. The data do not provide any indication of resetting or neocrystallization of titanite between these two events, supporting an absence of penetrative amphibolitefacies Sveconorwegian metamorphism and magmatism to the northeast of this boundary. The titanite data do not rule out Sveconorwegian localized deformation (faults or shear zones) or lowgrade metamorphism northeast of the boundary.

Two of the samples reported in this study, samples 6 and 4 from within the eclogite-bearing basement in the Nordøyane UHP domain, contain concordant to near-concordant Sveconorwegian zircon. Treated individually, the two samples do not yield credible or precise Sveconorwegian concordia or discordia ages. However, given the similarity of protolith ages and the proximity of the localities, the two samples are assumed to have undergone the same sequence of events and can be pooled together. The combined data include four analyses from two zircon crystals of sample 4 showing weak sector zoning (zircons 02 and 04, supplement 4; fig. $8 \mathrm{~L})$ and two analyses from two distinct rim textures

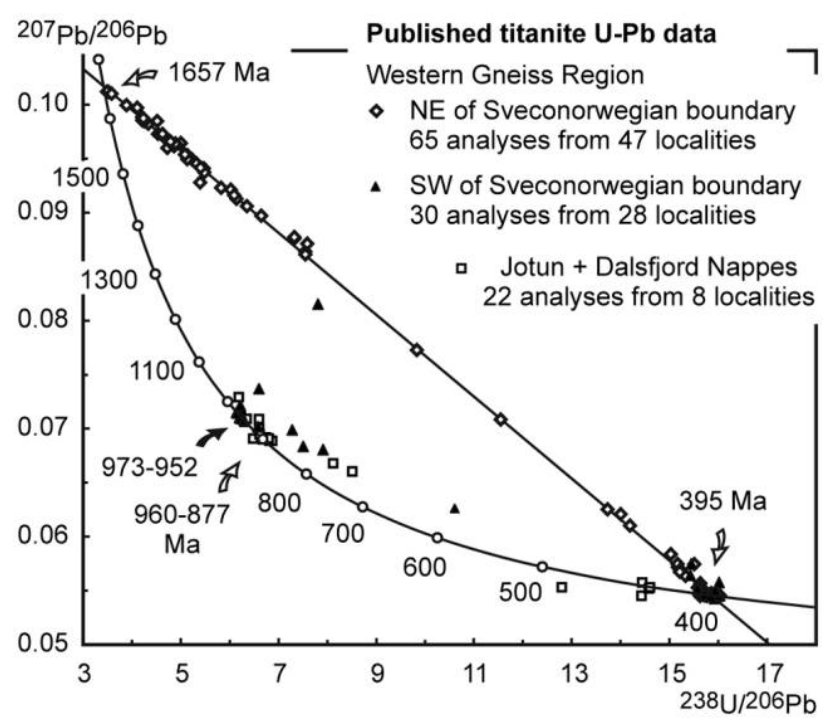

Figure 9. Compilation of published titanite $\mathrm{U}-\mathrm{Pb}$ data (isotope dilution-thermal ionization mass spectrometry data) from the Western Gneiss Region and Middle Allochthon Jotun and Dalsfjord Nappes. Data from Schärer (1980), Tucker et al. (1990, 2004), Corfu and Andersen (2002), Skår and Pedersen (2003), Lundmark and Corfu (2007, 2008), Lundmark et al. (2007), and Kylander-Clark et al. (2008). Sampling sites located to the northeast of the Sveconorwegian boundary (Romsdalen valley) define a discordia line between ca. 1657 and ca. $395 \mathrm{Ma}$, lacking evidence for Sveconorwegian influence. Sampling sites located to the southwest of the Sveconorwegian boundary and in the Dalsfjord and Jotun Nappes scatter between ca. 973 and $395 \mathrm{Ma}$, pointing to Sveconorwegian resetting or (re)crystallization. Note that concordant to near-concordant data from the Jotun and Dalsford Nappes (960-877 Ma) are nominally younger (though overlapping/ with the one of the southwestern part of the Western Gneiss Region (973-952 Ma).

dark in CL images in sample 6 (zircons 09 and 14; supplement 4; fig. 8A). As seen in figure $6 c$, these analyses define a short spread along the concordia curve with ${ }^{206} \mathrm{~Pb} /{ }^{238} \mathrm{U}$ ages ranging from $948 \pm 14$ to $894 \pm 14 \mathrm{Ma}$, suggesting lead loss at some later stage. If this lead loss is assumed to be Caledonian, a regression forced accordingly provides an upper intercept age of $950 \pm 25 \mathrm{Ma}$, constraining the timing of Sveconorwegian metamorphism at these localities. The Sveconorwegian zircon is characterized by a low $\mathrm{Th} / \mathrm{U}$ ratio $(\mathrm{Th} / \mathrm{U} \leq 0.07)$, typical for zircon grown during metamorphism (fig. 7). Low $\mathrm{Th} / \mathrm{U}$ zircon typically crystallizes in melt-absent, amphibolite-facies conditions or higher, fixing $\mathrm{Zr}$ originally distributed as a trace element in magmatic minerals (e.g., Bingen et al. 2001; Söderlund et al. 2002). Low $\mathrm{Th} / \mathrm{U}$ zircon forms in assemblage 
with a Th-rich mineral, which in these samples is most likely allanite (present in the rock today). Consequently, it is interpreted to reflect zircon neocrystallization related to Sveconorwegian metamorphism. Unsurprisingly, the EBSD image shows that the zircon rim grew epitaxially on the zircon core without detectable lattice misorientation.

The age of $950 \pm 25 \mathrm{Ma}$ overlaps available estimates of Sveconorwegian overprint in the WGR. The data do not permit us to decide if this zircon is coeval with garnet present in minor amounts in these two samples. However, widespread minor garnet in felsic gneisses in the HP to UHP domains of the WGR is known to be Caledonian ( $\mathrm{Sm}-\mathrm{Nd}$ data; Peterman et al. 2009), and consequently, the metamorphic assemblage observed today in these rocks is likely to be Caledonian. The samples were collected a short distance west of the projected "Sveconorwegian boundary" sketched by Tucker et al. (1990). So far, they represent the northernmost direct evidence for at least amphibolite-facies Sveconorwegian metamorphism in the Baltican Basement in the WGR and the rest of the Scandinavian Caledonides.

Scandian Overprint and Partial Resetting of Zircon. The geochronology of the Scandian HP to UHP metamorphism in the WGR is now well established by a variety of techniques applied to eclogite-facies rocks and associated small magmatic intrusions. Available data include whole-rock and mineral $\mathrm{Rb}$ $\mathrm{Sr}, \mathrm{Sm}-\mathrm{Nd}$, and Lu-Hf isochrons and U-Pb data on zircon, titanite, rutile, and monazite /Griffin and Bruekner 1980; Terry et al. 2000b; Tucker et al. 2004; Glodny et al. 2008; Kylander-Clark et al. 2008; Hacker et al. 2010; Krogh et al. 2011). The data indicate that equilibrium eclogite-facies assemblages crystallized during a protracted period beginning at ca. $420 \mathrm{Ma}$ and ending before $395 \mathrm{Ma}$.

The effect of Scandian HP to UHP and subsequent amphibolite-facies metamorphism on isotopic systems in the felsic gneisses hosting the eclogites is still poorly understood. Published U-Pb studies, mainly reporting isotope dilution analysis isotope dilution-thermal ionization mass spectrometry (ID-TIMS) of variably abraded crystals, indicate partial resetting of zircon and partial to total resetting of titanite during the Scandian event (Tucker et al. 1990, 2004; Austrheim et al. 2003). Titanite shows a strong increase in the degree of resetting toward the northwest, parallel to the increase in exhumation-related amphibolite-facies deformation in the Baltican Basement (fig. 9; Tucker et al. 1990, 2004; Kylander-Clark et al. 2008). Titanite in the northwesternmost areas yield largely concordant ages at ca. $395 \mathrm{Ma}$, recording late Scandian overprint and partial melting.

Four of the samples analyzed in this study (samples 1, 2, 3, and 8) show only limited evidence for post-Paleoproterozoic modification of the U-Pb signal. The other four samples $(4,5,6$, and 7$)$ show a fan-shaped scatter of SIMS and ICP-MS analyses in a concordia plot with an upper intercept value corresponding to the Paleoproterozoic magmatic crystallization. The fan-shaped scatter of analyses is consistent with an accumulation of Sveconorwegian and Scandian lead loss (figs. 5, 6). The ICP-MS and especially the SIMS analytical methods guided by CL imaging offers a good control (before and after analysis) on what domains are analyzed within the zircons, and great care has been taken to ensure that each analysis represents a single homogeneous crystal domain. Additionally, the lack of correlation between zircon $\mathrm{Th} / \mathrm{U}$ ratio and apparent ${ }^{206} \mathrm{~Pb} /$ ${ }^{238} \mathrm{U}$ age (fig. 7) suggests that age discordance does not result from mixed analyses of magmatic and metamorphic zircon. Consequently, we are confident that the distribution of points in the concordia diagram represents a real microscale scatter of composition rather than a mixing trend between zircon domains or growth zones of distinct ages.

The CL images of zircon crystals in samples 4 to 7 commonly show domains with convolute zoning, coarsening, or fading of the oscillatory zoning ("ghost zoning") and increased CL signal ("bleaching"; fig. 8). Such features are generally attributed to solid-state partial recrystallization of the protolith magmatic zircon, as a result of at least amphibolites-facies metamorphism (Hoskin and Black 2000). Increase of the CL signal can result from crystal recovery after radiation damage and loss of trace elements (Nasdala et al. 2003). Many of the discordant analyses in samples 4 to 7 were collected from such domains, suggesting that these features are largely Scandian and that their formation was associated with loss of radiogenic lead. However, some of the prominent luminescent domains, for example, in figure $8 H, 8 \mathrm{O}, 8 \mathrm{P}$, yield concordant Paleoproterozoic SIMS analyses, implying that no firm conclusion can be drawn on the exact timing of their formation.

No concordant Scandian zircon domain or zircon rim thick enough to be analyzed separately could be detected, suggesting that no significant neocrystallization of zircon took place during the Scandian metamorphism in these rocks. Two complementary explanations can be proposed. (1) Metamorphic neocrystallization of zircon consumes $\mathrm{Zr}$ stored as a trace element in magmatic 
minerals such as ilmenite and pyroxenes, when these minerals are converted into a metamorphic assemblage. This process takes place during the first high-grade event affecting the rock (Söderlund et al. 2002), that is, the Sveconorwegian event in the studied samples (figs. $6 c, 8 A, 8 L$ ). Zr fixed in zircon is commonly not remobilized during the following events, explaining why no new zircon was crystallized during the Scandian event. (2) Phasediagram calculations indicate that the eclogitefacies mineral assemblage for the bulk composition corresponding to the K-feldspar augen gneiss should contain ca. 2.5 vol\% garnet at $3 \mathrm{GPa}$ in equilibrium with jadeitic clinopyroxene and phengite (Peterman et al. 2009). However, like most of the felsic gneisses in the WGR, the five augen gneiss samples collected in the HP to UHP domains (samples 4-8) lack observable eclogite-facies mineral phases or any pseudomorphs after eclogitefacies minerals. Garnet could have grown during prograde, peak, or retrograde metamorphism $(\mathrm{Pe}-$ terman et al. 2009) but was not observed to contain eclogite-facies inclusions. These observations converge toward the widely held view that the bulk of the felsic gneisses never reacted to form eclogitefacies assemblages through the HP to UHP subduction-exhumation cycle, as a consequence of a shortage in catalyzing fluid components and the existence of kinetic barriers under a low temperature-high pressure metamorphic gradient (Austrheim et al. 1997, 2003; Wain et al. 2001; Peterman et al. 2009). The lack of metamorphic zircon neocrystallization in the analyzed samples corroborates this interpretation.

Link between Crystal Plastic Deformation of Zircon and Heterogeneous Lead Loss. Misorientation of the crystal lattice and low-angle boundaries visible on EBSD orientation maps of zircon are attributed to crystal plastic deformation, that is, formation and migration of dislocations and their accumulation into low-angle boundaries (Reddy et al. 2006, 2007, 2009). Crystal plastic deformation of zircon has been shown to be associated with fading of oscillatory growth zoning and a change in trace element chemistry (Reddy et al. 2006). Examples in the literature of reset or disturbed of U-Pb ages associated with zircon deformation are mainly related to meteorite impacts (e.g., Bohor et al. 1993; Nemchin et al 2009; Kamo et al. 2011; Tohver et al. 2012). The combination of EBSD data, CL imaging, and U-Pb data in samples 4 and 6, however, document such a relationship in the context of crustal deformation. Zircon 02 from sample 6 shows an interesting correlation between gradual disappearance of the os- cillatory zoning, lattice misorientation of up to $8^{\circ}$, and U-Pb discordance (fig. 8E, 8G). Discordance of the U-Pb system in this zircon increases from $4.1 \%$ in the oscillatory-zoned domain to $21.6 \%$ in the domain where the original zoning is faded, at constant $U$ and Th concentrations (figs. $6 b, 8 E, 8 F$ ). This suggests that dislocation creep associated with lattice deformation resulted in enhanced diffusion and removal of radiogenic lead. Zircon 08 from sample 4 provides another interesting correlation between the presence of dark linear features associated with the suppression of CL signal, a lowangle boundary in the EBSD orientation map (arrow in fig. $8 I, 8 J)$ and U-Pb discordance. U-Pb analysis 08 a was partly made on these features. This is the most discordant $(-26.6 \%)$ of the three analyses in this zircon $(-21.3 \%$ to $-26.6 \%)$ and also the most discordant analysis available for this sample (fig. $6 a$ ). This correlation indicates the formation and migration of dislocations to form low-angle boundaries, which provide rapid pathways for outward diffusion of radiogenic lead in zircon.

The misorientation boundaries observed in the four EBSD maps of samples 4 and 6 crosscut the main zones defined in the CL image, showing that these boundaries postdate growth zoning. This is especially evident for the low-angle boundary in the EBSD image of zircon 08, which matches a luminescent discontinuity in the CL image and cuts the entire crystal (fig. 8I, 8J). The distribution of U-Pb analyses in these samples indicates that the crystal plastic deformation of the zircon is related to the Scandian subduction-exhumation cycle.

Pre-Caledonian Terrain Linkage. There is a consensus that the WGR is a segment of Baltica (Fennoscandia) reworked during the Caledonian orogeny. The Sveconorwegian boundary as outlined by Tucker et al. (1990) in the WGR trends northwest and lies in apparent good alignment with the Sveconorwegian Frontal Deformation Zone (or Protogine Zone; fig. 1) that defines the eastern boundary of the Sveconorwegian Orogen to the southeast of the Caledonian nappe front. For this reason, a correlation has been proposed between the Baltican Basement in the WGR and the Eastern Segment of the Sveconorwegian orogen (fig. 1; Tucker et al. 1990; Gorbatschev and Bogdanova 1993). In both areas, there is an apparent lithological continuity between the domain affected by Sveconorwegian overprint in the west and the one unaffected by this overprint in the east. The Eastern Segment is generally interpreted as a reworked part of the Transscandinavian Igneous Belt, exposed directly to the east of the Sveconorwegian Orogen in Sweden. 
The magmatic and metamorphic events in the WGR largely overlap with the ones in the Eastern Segment (fig. 10). In the Eastern Segment, metamorphic zircon in high-grade rocks and zircon from associated synmetamorphic pegmatites range from $992 \pm 24$ to $949 \pm 4 \mathrm{Ma}$ with a frequency maximum around $970 \mathrm{Ma}$ (compilation in Bingen et al. 2008; Söderlund et al. 2002) and titanite U-Pb ages range from ca. 962 to $923 \mathrm{Ma}$. In the WGR, zircon ages from equivalent settings range from $987 \pm$ 10 to $942+5 /-3 \mathrm{Ma}$, and concordant titanite ages range from ca. 973 to $952 \mathrm{Ma}$ (fig. 9; Tucker et al. 1990; Skår and Pedersen 2003; Røhr et al. 2004; Glodny et al. 2008; Kylander-Clark et al. 2008; this work). Although this match supports the correlation, recent data and data of this study also call attention to some differences. (1) The main alkalicalcic to calc-alkaline crust forming magmatic event in the WGR peaked at ca. $1655 \mathrm{Ma}$ (1686$1594 \mathrm{Ma})$. It is distinctly younger than the magmatism characterizing the Eastern Segment, which peaked at ca. $1690 \mathrm{Ma}$ (1795-1640 Ma; compilation in Bingen et al. 2011). (2) The southern part of the Eastern Segment (southern Sweden) was affected by an amphibolite-facies metamorphic event at ca. 1460-1400 Ma, called Hallandian (Söderlund et al. 2002; Brander et al. 2012). The evidence for this metamorphism fades northward and is, as far as we

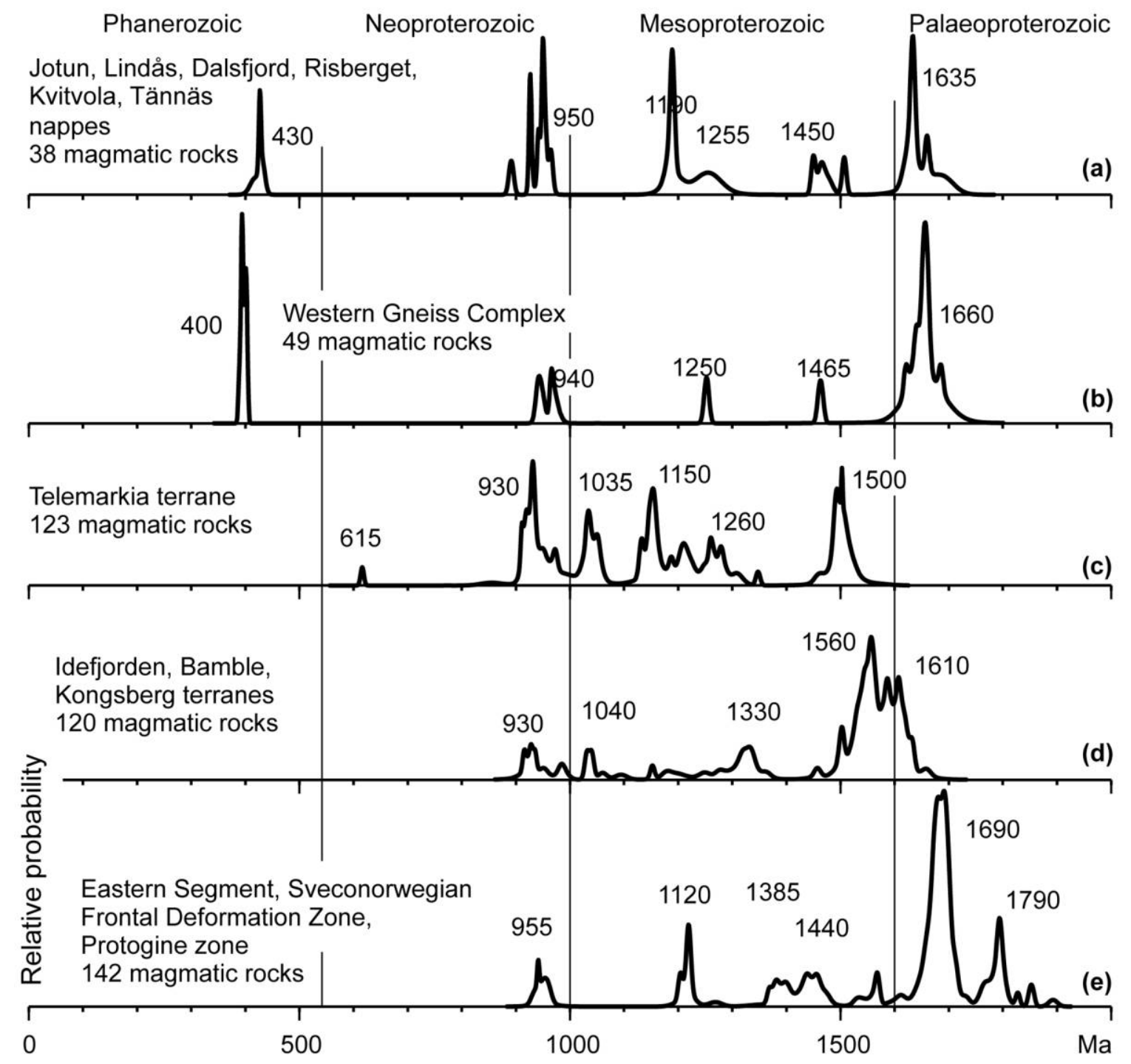

Figure 10. Probability density distributions of the magmatic ages characterizing the blocks or terranes mentioned in the discussion. Sources: Bingen and Solli (2009), with additions from Brander et al. (2012); Krogh et al. (2011); Lamminen et al. (2011); Vander Auwera et al (2011). 
can tell, lacking in the WGR. (3) In the southern part of the Eastern Segment, Sveconorwegian metamorphism has a clear high-pressure signature, peaking with high-pressure granulite-facies to eclogite-facies conditions $(P>1.5 \mathrm{GPa}$; Möller 1998; Johansson et al. 2001). This metamorphism disappears northward in the Eastern Segment. The few available pressure-temperature estimates from Sveconorwegian granulites in the WGR suggest significantly lower pressures $(1 \mathrm{GPa}$; Engvik et al. 2000; Wain et al. 2001). (4) The WGR hosts a few large Sveconorwegian postorogenic granite plutons (Jølster pluton), while the Eastern Segment does not. Following these arguments, a direct correlation between the Baltican Basement in the WGR and the Eastern Segment can be disputed. The difficulties in establishing a direct correlation, however, do not necessarily mean that there is a major terrane boundary hidden somewhere beneath the Caledonian nappes that would separate these segments. Instead, these probably represent two slightly different marginal segments of Baltica into which Sveconorwegian deformation and metamorphism propagated after ca. $990 \mathrm{Ma}$, during the late stages of Sveconorwegian orogenesis (Bingen et al. 2008).

A correlation between the Baltican Basement in the WGR and the Idefjorden terrane in the Sveconorwegian Orogen was implicitly proposed when including the Paleoproterozoic felsic magmatism in the WGR as part of the so-called Gothian event (Austrheim et al. 2003; Skår and Pedersen 2003). The Gothian term has been used in a restricted sense in recent publications, for active margin magmatism and processes between ca. 1660 and 1520 $\mathrm{Ma}$, as recorded in the Idefjorden terrane (Åhäll and Connelly 2008; Bingen et al. 2008). There is indeed a partial overlap between the age of magmatism in the WGR (1686-1594 Ma) and the typical calcalkaline magmatism in the Idefjorden terrane (1659-1520 Ma; fig. 10). A direct correlation, however, is not appropriate as the WGR is apparently lacking the prominent 1555-1545 Ma volcanic-arc magmatism in the Idefjorden terrane (Hisingen suite) and associated thick packages of greywacke sediment (Stora Le-Marstrand formation; Andersen et al. 2004; Åhäll and Connelly 2008). The WGR and the Idefjorden terrane should be interpreted as two distinct growth zones of Paleoproterozoic to Mesoproterozoic Baltica.

Missing Magmatic Suites. This study fails to confirm the existence of significant Mesoproterozoic felsic magmatism at around $1500 \mathrm{Ma}$ in the WGR (samples 6, 4, and 5; figs. 5 and 6), invalidating early data by Lappin et al. (1979), Carswell and Harvey
(1985), and Tucker et al. (1990). Magmatic rocks at ca. $1500 \mathrm{Ma}$ are important because they have been regarded as part of a large scale "stitching" magmatism in Mesoproterozoic Baltica (Fennoscandia). More specifically, the voluminous Rjukan continental rift volcanism dated at around 1510-1495 $\mathrm{Ma}$ (Bingen et al. 2005; Laajoki and Corfu 2007) and associated plutonism in the Telemarkia terrane of the Sveconorwegian Orogen, are coeval with a suite of small ca. 1536-1495 Ma rapakivi plutons exposed along a N-S-trending axis in central Sweden called the "Ragunda suite" (Åhäll et al. 2000; Andersson et al. 2002). The occurrence of ca. $1500 \mathrm{Ma}$ plutons in an area intermediate between cratonic Fennoscandia and the presumably most transported terrane of the Sveconorwegian orogenic belt, the Telemarkia terrane, would be an argument to interpret the entire ca. $1500 \mathrm{Ma}$ magmatism as part of a widespread and continuous magmatic suite intruding one plate. Theories concerning the exotic ancestry of the Telemarkia terrane (Bingen et al. 2008) are therefore not falsified by the results presented here.

As outlined earlier, the Middle Allochthon Risberget Nappe is characterized by augen gneisses dated to ca. 1650-1640 Ma and 1190-1180 Ma (Handke et al. 1995; Robinson 1995). Sample 3 collected from the Helleneset Synform in Brattvåg, yields a magmatic protolith age of $1676 \pm 18 \mathrm{Ma}$ (fig. $5 \mathrm{c}$ ) and fails to provide another occurrence of the more diagnostic 1190-1180 Ma augen gneiss. Following this result, the Risberget Nappe cannot be mapped unambiguously along the southern flank of the Helleneset Synform. Slices of $1193 \pm$ 15 to $1183 \pm 7 \mathrm{Ma}$ augen gneiss and anorthosite have recently been traced in the Middle Allochthon Kvitovola Nappes ca. $200 \mathrm{~km}$ southeast of the study area (Lamminen et al. 2011), suggesting that this rock suite is much more extensive in the Middle Allochthon than previously assumed. Neither this nor previous studies have managed to uncover plutonic rocks aged ca. 1190-1180 Ma westward, especially in the Baltican Basement of the WGR. Such rocks could provide clear evidence that the Middle Allochthon Risberget and Kvitvola Nappes could include slabs of the underlying Baltican Basement exposed in the WGR that were transported southeastward during the Scandian orogeny. The provenance of the Risberget and Kvitvola Nappes therefore remains enigmatic. Felsic magmatism at 1190$1180 \mathrm{Ma}$ is well known in the Telemarkia and Bamble terranes in the Sveconorwegian Orogen (e.g., Gjerstad augen gneiss; Heaman and Smalley 1994) in crust much younger than $1650 \mathrm{Ma}$ or in the Gardar bimodal volcanic rift in the Ketilidian Orogen 
of Greenland (Laurentia) in crust much older than $1650 \mathrm{Ma}$.

Evidence for Grenvillian/ Sveconorwegian magmatism and metamorphism is found within allochthonous units in northeast Greenland and in northern Scandinavia (Kalsbeek et al. 2000; Leslie and Nutman 2003; Johansson et al. 2004; Kirkland et al. 2006, 2007; Myhre et al. 2009; Be'eri-Shlevin et al. 2011). While this study does not offer any solution to the origin of these allochthonous units, it is evident that the WGR hosts the northernmost traces of Sveconorwegian metamorphism within crust of unquestionable Baltica ancestry. Continued geochronological work in this area may therefore provide some of the data needed to solve this puzzle.

\section{Conclusions}

1. The bulk of the Paleoproterozoic felsic magmatism in the WGR took place between $1686 \pm$ 2 and $1633 \pm 8 \mathrm{Ma}$, with a peak at ca. $1655 \mathrm{Ma}$. Locally, it continued to $1594 \pm 10 \mathrm{Ma}$. No significant difference in age is observed between the eclogite-bearing and the eclogite-free domains inside the WGR, confirming that these domains are part of the same crustal segment. The study fails to confirm the existence of a Mesoproterozoic, ca. $1500 \mathrm{Ma}$ felsic magmatic suite in the WGR and also fails to uncover ca. 1180 Ma magmatism, both of which are important markers for terrain linkage in and around Baltica.

2. Two samples contain a minor proportion of low $\mathrm{Th} / \mathrm{U}$ neocrystallized zircon with an age of $950 \pm 25 \mathrm{Ma}$. They offer new evidence for at least amphibolite-facies Sveconorwegian metamorphism in the Baltican Basement of the WGR. They corroborate the existence and position of the "Sveconorwegian boundary" proposed by Tucker et al. (1990) and represent the northernmost point in the Scandinavian Caledonides to show a Sveconorwegian overprint in a basement of unquestionable Baltica ancestry.

3. No neocrystallization of metamorphic zircon is detected in the felsic orthogneisses during the Scandian HP to UHP event and following exhumation through amphibolite-facies conditions. This suggests that the felsic orthogneisses did not convert to eclogite during peak metamorphism. Instead, partial solid-state recrystallization of the protolith magmatic oscillatory-zoned zircon is widespread in some of the samples from the HP to UHP domains.

4. Combined EBSD data, CL images, and U-Pb data in samples from the HP to UHP domains document heterogeneous crystal plastic deformation of zircon during the Scandian metamorphic and tectonic event. The data provide evidence for a correlation between reduced oscillatory growth zoning, crystal plastic deformation, and radiogenic lead loss in zircon. They also provide evidence for a link between linear dark zones of suppressed CL signal, low-angle orientation boundaries, and radiogenic lead loss.

5. The Baltican Basement in the WGR (16861594 Ma magmatism) cannot be directly correlated with the Eastern Segment of the Sveconorwegian Orogen (1795-1640 Ma magmatism) or with the Idefjorden terrane hosting the type Gothian active margin magmatism (1659-1520 Ma magmatism). The Baltican Basement in the WGR and the Eastern Segment probably represent two slightly different marginal growth zones of Baltica into which Sveconorwegian reworking propagated during the final phases of Sveconorwegian orogenesis, after ca. 990 Ma.

\section{A C K N O W LEDGMENTS}

Collection by Robinson in 2009 of samples 3-8 was assisted by Jared Butler, Yaron Be'eri-Shlevin, and Rebeckah Jamieson, and of sample 2 by Alexandra McEnroe. SIMS data were collected at the NORDSIM facility in Stockholm, operated under an agreement between the research funding agencies of Denmark, Norway, Sweden, Finland, the Geological Survey, and the Swedish Museum of Natural History. SIMS data were collected under the supervision of L. Ilyinsky, K. Lindén, and M. J. Whitehouse. This is NORDSIM publication 314. LA-ICP-MS data were collected at the laboratory of the Geological Survey of Norway under the supervision of Ø. Skår. This article benefited from constructive criticism by F. Corfu, an anonymous reviewer, and Editor D. B. Rowley.

\section{R E F E R E N C E S C I T E D}

Åhäll, K.-I., and Connelly, J. N. 2008. Long-term convergence along SW Fennoscandia: 330 m.y. of Proterozoic crustal growth. Precambrian Res. 161:452-472.

Åhäll, K.-I.; Connelly, J. N.; and Brewer, T. S. 2000. Ep- isodic rapakivi magmatism due to distal orogenesis? correlation of 1.69-1.50 Ga orogenic and inboard, "anorogenic" events in the Baltic Shield. Geology 28:823826. 
Andersen, T. B. 1998. Extensional tectonics in the Caledonides of southern Norway, an overview. Tectonophysics 285:333-351.

Andersen, T.; Griffin, W. L.; Jackson, S. E.; Knudsen, T.L.; and Pearson, N. J. 2004. Mid-Proterozoic magmatic arc evolution at the southwest margin of the Baltic Shield. Lithos 73:289-318.

Andersson, U. B.; Neymark, L. A.; and Billström, K. 2002. Petrogenesis of Mesoproterozoic (Subjotnian) rapakivi complexes of central Sweden: implications from U-Pb zircon ages, $\mathrm{Nd}, \mathrm{Sr}$ and $\mathrm{Pb}$ isotopes. Trans. R. Soc. Edinb. Earth Sci. 92:201-228.

Austrheim, H., and Corfu, F. 2009. Formation of planar deformation features (PDFs) in zircon during coseismic faulting and an evaluation of potential effects on U-Pb systematics. Chem. Geol. 261:25-31.

Austrheim, H.; Corfu, F.; Bryhni, I.; and Andersen, T. B. 2003. The Proterozoic Hustad igneous complex: a low strain enclave with a key to the history of the Western Gneiss Region of Norway. Precambrian Res. 120:149175.

Austrheim, H.; Erambert, M.; and Engvik, A. K. 1997. Processing of crust in the root of the Caledonian continental collision zone: the role of eclogitization. Tectonophysics 273:129-153.

Be'eri-Shlevin, Y.; Gee, D. G.; Claesson, S.; Ladenberger, A.; Majka, J.; Kirkland, C. L.; Robinson, P.; and Frei, D. 2011. Provenance of Neoproterozoic sediments in the Särv nappes (Middle Allochthon) of the Scandinavian Caledonides: LA-ICP-MS and SIMS U-Pb dating of detrital zircons. Precambrian Res. 187:181-200.

Bingen, B.; Belousova, E. A.; and Griffin, W .L. 2011. Neoproterozoic recycling of the Sveconorwegian orogenic belt: detrital-zircon data from the Sparagmite basins in the Scandinavian Caledonides. Precambrian Res. 189:347-367.

Bingen, B.; Davis, W. J.; and Austrheim, H. 2001. Zircon $\mathrm{U}-\mathrm{Pb}$ geochronology in the Bergen arc eclogites and their Proterozoic protoliths, and implications for the pre-Scandian evolution of the Caledonides in western Norway. Geol. Soc. Am. Bull. 113:640-649.

Bingen, B.; Nordgulen, Ø.; and Viola, G. 2008. A fourphase model for the Sveconorwegian orogeny, SW Scandinavia. Nor. J. Geol. 88:43-72.

Bingen, B.; Skår, Ø.; Marker, M.; Sigmond, E. M. O.; Nordgulen, Ø.; Ragnhildstveit, J.; Mansfeld, J.; Tucker, R. D.; and Liégeois, J.-P. 2005. Timing of continental building in the Sveconorwegian orogen, SW Scandinavia. Nor. J. Geol. 85:87-116.

Bingen, B., and Solli, A. 2009. Geochronology of magmatism in the Caledonian and Sveconorwegian belts of Baltica: synopsis for detrital zircon provenance studies. Nor. J. Geol. 89:267-290.

Bohor, B. F.; Betterton, W. J.; and Krogh, T. E. 1993. Impact-shocked zircons: discovery of shock-induced textures reflecting increasing degrees of shock metamorphism. Earth Planet. Sci. Lett. 119:419-424.

Braathen, A., Nordgulen, Ø., Osmundsen, P.-T., Andersen, T. B., Solli, A. and Roberts, D. 2000. Devonian, orogen-parallel, opposed extension in the central Norwegian Caledonides. Geology 28:615-618.

Brander, L.; Appelquist, K.; Cornell, D.; and Andersson, U. B. 2012. Igneous and metamorphic geochronologic evolution of granitoids in the central Eastern Segment, southern Sweden. Int. Geol. Rev. 54:509-546.

Brueckner, H. K.; Carswell, D. A.; Griffin, W. L.; Medaris, L. G.; Van Roermund, H. L. M.; and Cuthbert, S. J. 2010. The mantle and crustal evolution of two garnet peridotite suites from the Western Gneiss Region, Norwegian Caledonides: an isotopic investigation. Lithos 117:1-19.

Carswell, D. A., and Harvey, M. A. 1985. The intrusive history and tectonometamorphic evolution of the Basal Gneiss Complex in the Moldefjord area, west Norway. In Gee, D. G., and Sturt, B. A., eds. The Caledonide Orogen: Scandinavia and related areas. Chichester, Wiley, p. 843-857.

Cavosie, A. J.; Quintero, R. R.; Radovan, H. A.; and Moser, D. E. 2010. A record of ancient cataclysm in modern sand: shock microstructures in detrital minerals from the Vaal River, Vredefort Dome, South Africa. Geol. Soc. Am. Bull. 122:1968-1980.

Claesson, S. 1980. A Rb-Sr isotope study of granitoids and related mylonites in the Tännäs Augen Gneiss Nappe, southern Swedish Caledonides. Geol. Foren. Stock. Forh. 102:403-420.

Corfu, F. 1980. U-Pb and Rb-Sr systematics in a polyorogenic segment of the Precambrian shield, central southern Norway. Lithos 13:305-323.

Corfu, F., and Andersen, T. B. 2002. U-Pb ages of the Dalsfjord Complex, SW Norway, and their bearing on the correlation of allochthonous crystalline segments of the Scandinavian Caledonides. Int. J. Earth Sci. 91: 955-963.

Corfu, F.; Gerber, M.; Andersen, T. B.; Torsvik, T. H.; and Ashwal, L. D. 2011. Age and significance of Grenvillian and Silurian orogenic events in the Finnmarkian Caledonides, northern Norway. Can. J. Earth Sci. 48: 419-440.

Cuthbert, S. J.; Carswell, D. A.; Krogh-Ravna, E. J.; and Wain, A. 2000. Eclogites and eclogites in the Western Gneiss Region, Norwegian Caledonides. Lithos 52: 165-195.

Engvik, A. K.; Austrheim, H.; and Andersen, T. B. 2000. Structural, mineralogical and petrophysical effects on deep crustal rocks of fluid-limited polymetamorphism, Western Gneiss Region, Norway. J. Geol. Soc. Lond. 157:121-134.

Gee, D. G. 1980. Basement-cover relationships in the central Scandinavian Caledonides. Geol. Foren. Stockh. Forh. 102:455-474.

Glodny, J.; Kuhn, A.; and Austrheim, H. 2008. Diffusion versus recrystallization processes in $\mathrm{Rb}-\mathrm{Sr}$ geochronology: isotopic relics in eclogite facies rocks, Western Gneiss region, Norway. Geochim. Cosmochim. Acta 72:506-525.

Gorbatschev, R., and Bogdanova, S. 1993. Frontiers in the Baltic Shield. Precambrian Res. 64:3-21.

Griffin, B. J., and Brueckner, H. 1980. Caledonian Sm-Nd 
ages and a crustal origin for Norwegian eclogites. Nature 285:319-321.

Hacker, B. R. 2006. Pressures and temperatures of ultrahigh-pressure metamorphism: implications for UHP tectonics and $\mathrm{H}_{2} \mathrm{O}$ in subducting slabs. Int. Geol. Rev. 48:1053-1066.

Hacker, B. R.; Andersen, T. B.; Johnston, S.; KylanderClark, A. R. C.; Peterman, E. M.; Walsh, E. O.; and Young, D. 2010. High-temperature deformation during continental-margin subduction and exhumation: the ultrahigh-pressure Western Gneiss Region of Norway. Tectonophysics 480:149-171.

Handke, M. J.; Tucker, R. D.; and Robinson, P. 1995. Contrasting $\mathrm{U}-\mathrm{Pb}$ ages for the Risberget augen gneiss in the Norwegian Caledonides; getting to the root of the problem. Geol. Soc. Am. Abstr. Program 27:226.

Heaman, L. M., and Smalley, P. C. 1994. A U-Pb study of the Morkheia Complex and associated gneisses, southern Norway: implications for disturbed $\mathrm{Rb}-\mathrm{Sr}$ systems and for the temporal evolution of Mesoproterozoic magmatism in Laurentia. Geochim. Cosmochim. Acta 58:1899-1911.

Hollocher, K.; Robinson, P.; Walsh, E.; and Terry, M. P. 2007. The Neoproterozoic Ottfjället dike swarm of the Middle Allochthon, traced geochemically into the Scandian Hinterland, Western Gneiss Region, Norway. Am. J. Sci. 307:901-953.

Hoskin, P. W. O., and Black, L. P. 2000. Metamorphic zircon formation by solid-state recrystallization of protolith igneous zircon. J. Metamorph. Geol. 18:423439.

Johansson, Å.; Larionov, A. N.; Gee, D. G.; Ohta, Y.; Tebenkov, A. M.; and Sandelin, S. 2004. Grenvillian and Caledonian tectono-magmatic activity in northeasternmost Svalbard. In Gee, D. G., and Pease, V. eds. The Neoproterozoic Timanide Orogen of Eastern Baltica. Geol. Soc. Lond., p. 207-232.

Johansson, L.; Möller, C.; and Söderlund, U. 2001. Geochronology of eclogite facies metamorphism in the Sveconorwegian Province of SW Sweden. Precambrian Res. 106:261-275.

Kalsbeek, F.; Thrane, K.; Nutman, A. P.; and Jepsen, H. F. 2000. Late Mesoproterozoic to early Neoproterozoic history of the East Greenland Caledonides: evidence for Grenvillian orogenesis? J. Geol. Soc. Lond. 157: 1215-1225.

Kamo, S. L.; Lana, C.; and Morgan, J. V. 2011. U-Pb ages of shocked zircon grains link distal K-Pg boundary sites in Spain and Italy with the Chicxulub impact. Earth Planet. Sci. Lett. 310:401-408.

Kirkland, C. L.; Daly, J. S.; and Whitehouse, M. J. 2006. Granitic magmatism of Grenvillian and late Neoproterozoic age in Finnmark, Arctic Norway: constraining pre-Scandian deformation in the Kalak Nappe Complex. Precambrian Res. 145:24-52.

Kirkland, C. L.; Daly, J. S.; and Whitehouse, M. J. 2007. Provenance and terrane evolution of the Kalak Nappe Complex, Norwegian Caledonides: implications for Neoproterozoic paleogeography and tectonics. J. Geol. 115:21-41.
Krill, A. G.; 1980. Tectonics of the Oppdal area, central Norway. Geol. Foren. Stockh. Forh. 102:523-530.

Krogh-Ravna, E. J.; and Terry, M. P. 2004. Geothermobarometry of UHP and HP eclogites and schists: an evaluation of equilibria among garnet-clinopyroxenekyanite-phengite-coesite/quartz. J. Metamorph. Geol. 22:579-592.

Krogh, T. E.; Kamo, S. L.; Robinson, P.; Terry, M. P.; and Kwok, K. 2011. U-PB zircon geochronology of eclogites from the Scandian Orogen, northern Western Gneiss Region, Norway: 14-20 Myr between eclogite crystallization and return to amphibolite facies conditions. Can. J. Earth Sci. 48:441-472.

Kylander-Clark, A. R. C.; Hacker, B. R.; Johnson, C. M.; Beard, B. L.; Mahlen, N. J.; and Lapen, T. J. 2007. Coupled Lu-Hf and Sm-Nd geochronology constrains prograde and exhumation histories of high- and ultrahighpressure eclogites from western Norway. Chem. Geol. 242:137-154.

Kylander-Clark, A. R. C.; Hacker, B. R.; and Mattinson, J. M. 2008. Slow exhumation of UHP terranes: titanite and rutile ages of the Western Gneiss Region, Norway. Earth Planet. Sci. Letters 272:531-540.

Laajoki, K., and Corfu, F. 2007. Lithostratigraphy of the Mesoproterozoic Vemork formation, central Telemark, Norway. Bull. Geol. Soc. Finl. 79:41-67.

Labrousse, L., Jolivet, L., Agard, P., Hebert, R. and Andersen, T. B. 2002. Crustal-scale boudinage and migmatization of gneiss during their exhumation in the UHP Province of Western Norway. Terra Nova 14: 263-270.

Lamminen, J.; Andersen, T.; and Nystuen, J. P. 2011. Zircon $\mathrm{U}-\mathrm{Pb}$ ages and Lu-Hf isotopes from basement rocks associated with Neoproterozoic sedimentary successions in the Sparagmite Region and adjacent areas, South Norway: the crustal architecture of western Baltica. Nor. J. Geol. 91:35-55.

Lappin, M. A.; Pidgeon, R. T.; and van Breemen, O. 1979. Geochronology of basal gneisses and mangerite syenites of Stadlandet, West Norway. Nor. Geol. Tidsskr. 59:161-181.

Leslie, A. G., and Nutman, A. P. 2003. Evidence for Neoproterozoic orogenesis and early high temperature Scandian deformation events in the southern East Greenland Caledonides. Geol. Mag. 140:309-333.

Lundmark, A., and Corfu, F. 2008. Late-orogenic Sveconorwegian massif anorthosite in the Jotun Nappe Complex, SW Norway, and causes of repeated AMCG magmatism along the Baltoscandian margin. Contrib. Mineral. Petrol. 155:147-163.

Lundmark, A. M., and Corfu, F. 2007. Age and origin of the Årdal dike complex, SW Norway: false isochrons, incomplete mixing, and the origin of Caledonian granites in basement nappes. Tectonics 26:TC2007.

Lundmark, A. M.; Corfu, F.; Spürgin, S.; and Selbekk, R. S. 2007. Proterozoic evolution and provenance of the high-grade Jotun Nappe Complex, SW Norway: U-Pb geochronology. Precambrian Res. 159:133-154.

Maniar, P. D., and Piccoli, P. M. 1989. Tectonic discrim- 
ination of granitoids. Geol. Soc. Am. Bull. 101:635643.

Möller, C. 1998. Decompressed eclogites in the Sveconorwegian (-Grenvillian) orogen of SW Sweden: petrology and tectonic implications. J. Metamorph. Geol. 16:641-656.

Moser, D. E.; Davis, W. J.; Reddy, S. M.; Flemming, R. L.; and Hart, R. J. 2009. Zircon U-Pb strain chronometry reveals deep impact-triggered flow. Earth Planet. Sci. Lett. 277:73-79.

Nasdala, L., Zhang, M., Kempe, U., Panczer, G., Gaft, M., Andrut, M., and Plötze, M. 2003. Spectroscopic methods applied to zircon. In Hanchar, J. M., and Hoskin, P. W. O., eds. Zircon. Rev. Mineral. Geochem. 53:427467.

Nemchin, A.; Timms, N. E.; Pidgeon, R.; Geisler, T.; Reddy, S. M.; and Meyer, C. 2009. Timing of crystallisation of the Lunar Magma Ocean constrained by the oldest zircon. Nature Geosci. 2:133-136.

Pearce, J. A.; Harris, N. B. W.; and Tindle, A. G. 1984. Trace element discrimination diagrams for the tectonic interpretation of granitic rocks. J. Petrol. 25:956983.

Peterman, E. M.; Hacker, B. R.; and Baxter, E. F. 2009. Phase transformations of continental crust during subduction and exhumation: Western Gneiss Region, Norway. Eur. J. Mineral. 21:1097-1118.

Reddy, S. M.; Timms, N. E.; and Eglington, B. M. 2008. Electron backscatter diffraction analysis of zircon: a systematic assessment of match unit characteristics and pattern indexing optimization. Am. Mineral. 93: 187-197.

Reddy, S. M.; Timms, N. E.; Hamilton, P. J.; and Smyth, H. R. 2009. Deformation-related microstructures in magmatic zircon and implications for diffusion. Contrib. Mineral. Petrol. 157:231-244.

Reddy, S. M.; Timms, N. E.; Pantleon, W.; and Trimby, P. 2007. Quantitative characterization of plastic deformation of zircon and geological implications. Contrib. Mineral. Petrol. 153:625-645.

Reddy, S. M.; Timms, N. E.; Trimby, P.; Kinny, P. D.; Buchan, C.; and Blake, K. 2006. Crystal-plastic deformation of zircon: a defect in the assumption of chemical robustness. Geology 34:257-260.

Roberts, D. 2003. The Scandinavian Caledonides: event chronology, palaeographic settings and likely modern analogues. Tectonophysics 365:283-299.

Roberts, D., and Gee, D. G. 1985. An introduction to the structure of the Scandinavian Caledonides. In Gee, D. G., and Sturt, B. A., eds. The Caledonide Orogen: Scandinavia and related areas. Chichester, Wiley, p. 55-68.

Robinson, P. 1995. Extension of Trollheimen tectonostratigraphic sequence in deep synclines near Molde and Brattvåg, Western Gneiss Region, southern Norway. Nor. Geol. Tidsskr. 75:181-197.

Robinson, P., and Hollocher, K. 2008a. Geology of Trollheimen. In Robinson, P.; Roberts, D.; and Gee, D. G., eds. Guidebook: a tectonostratigraphic transect across the central Scandinavian Caledonides. NGU report
2008.064, pt. II. Trondheim, Geological Survey of Norway, p. 6-1-6-7.

2008b. Mafic dikes and basement-cover relationships, southern coast of islands of Midsund. In Robinson, P.; Roberts, D.; and Gee, D. G., eds. Guidebook: a tectono-stratigraphic transect across the central Scandinavian Caledonides, NGU report 2008.064, pt. II. Trondheim, Geological Survey of Norway, p. 717-7-22.

Root, D. B.; Hacker, B. R.; Gans, P. B.; Ducea, M. N.; Eide, E. A.; and Mosenfelder, J. L. 2005. Discrete ultrahigh-pressure domains in the Western Gneiss Region, Norway: implications for formation and exhumation. J. Metamorph. Geol. 23:45-61.

Røhr, T. S.; Corfu, F.; Austrheim, H.; and Andersen, T. B. 2004. Sveconorwegian U-Pb zircon and monazite ages of granulite-facies rocks, Hisarøya, Gulen, Western Gneiss Region, Norway. Nor. J. Geol. 84:251-256.

Schärer, U. 1980. U-Pb and Rb-Sr dating of a polymetamorphic nappe terrain: the Caledonian Jotun Nappe, southern Norway. Earth Planet. Sci. Lett. 49:205-218.

Skår, Ø. 2000. Field relations and geochemical evolution of the Gothian rocks in the Kvamsøy area, southern Western Gneiss Complex, Norway. NGU Bull. 437:523.

Skår, Ø.; Furnes, H.; and Claesson, S. 1994. Middle Proterozoic magmatism within the Western Gneiss Region, Sunnfjord, Norway. Nor. Geol. Tidsskr. 74:114126.

Skår, Ø., and Pedersen, R. B. 2003. Relations between granitoid magmatism and migmatization: $\mathrm{U}-\mathrm{Pb}$ geochronological evidence from the Western Gneiss Complex, Norway. J. Geol. Soc. Lond. 160:935-946.

Söderlund, U.; Möller, C.; Andersson, J.; Johansson, L.; and Whitehouse, M. 2002. Zircon geochronology in polymetamorphic gneisses in the Sveconorwegian orogen, SW Sweden: ion microprobe evidence for 1.46-1.42 and 0.98-0.96 Ga reworking. Precambrian Res. 113:193-225.

Terry, M. P., and Robinson, P. 2003. Evolution of amphibolite-facies structural features and boundary conditions for deformation during exhumation of highand ultrahigh-pressure rocks, Nordøyane, Western Gneiss Region, Norway. Tectonics 22:TC001349.

- 2004. Geometry of eclogite-facies structural features: implications for production and exhumation of ultrahigh-pressure and high-pressure rocks, Western Gneiss Region, Norway. Tectonics 23:TC2001.

Terry, M. P.; Robinson, P.; and Ravna, E. J. K. $2000 a$. Kyanite eclogite thermobarometry and evidence for thrusting of UHP over HP metamorphic rocks, Nordøyane, Western Gneiss Region, Norway. Am. Mineral. 85:1637-1650.

Terry, M. P.; Robinson, P.; Hamilton, M. A.; and Jercinovic, M. J. 2000b. Monazite geochronology of UHP and HP metamorphism, deformation, and exhumation, Nordøyane, Western Gneiss Region, Norway. Am. Mineral. 85:1651-1664.

Timms, N. E.; Kinny, P. D.; and Reddy, S. M. 2006. En- 
hanced diffusion of uranium and thorium linked to crystal plasticity in zircon. Geochem. Trans. 7:10.

Timms, N. E.; Kinny, P. D.; Reddy, S. M.; Evans, K.; Clark, C.; and Healy, D. 2011. Relationship among titanium, rare earth elements, $\mathrm{U}-\mathrm{Pb}$ ages and deformation microstructures in zircon: implications for Ti-in-zircon thermometry. Chem. Geol. 280:33-46.

Timms, N. E.; Reddy, S. M.; Fitz Gerald, J. D.; Green, L.; and Muhling, J. R. 2012. Inclusion-localised crystalplasticity, dynamic porosity, and fast-diffusion pathway generation in zircon. J. Struct. Geol. 35:78-89.

Tohver, E.; Lana, C.; Cawood, P. A.; Fletcher, I. R.; Jourdan, F.; Sherlock, S.; Rasmussen, B.; et al. 2012. Geochronological constraints on the age of a Permo-Triassic impact event: $\mathrm{U}-\mathrm{Pb}$ and ${ }^{40} \mathrm{Ar} /{ }^{39} \mathrm{Ar}$ results for the $40 \mathrm{~km}$ Araguainha structure of central Brazil. Geochim. Cosmochim. Acta 86:214-227.

Tucker, R. D.; Krogh, T. E.; and Råheim, A. 1990. Proterozoic evolution and age-province boundaries in the central part of the Western Gneiss Region, Norway: results of $\mathrm{U}-\mathrm{Pb}$ dating of accessory minerals from Trondheimsfjord to Geiranger. In Gower, C. F.; Rivers, T.; and Ryan, A. B., eds. Mid-Proterozoic LaurentiaBaltica. Geol. Assoc. Can. Spec. Pap. St. John's, Geological Association of Canada, p. 149-173.

Tucker, R. D.; Råheim, A.; Krogh, T. E.; and Corfu, F. 1987. Uranium-lead zircon and titanite ages from the northern portion of the Western Gneiss Region, southcentral Norway. Earth Planet. Sci. Lett. 81:203-211.

Tucker, R. D.; Robinson, P.; Solli, A.; Gee, D. G.; Thorsnes, T.; Krogh, T. E.; Nordgulen, Ø.; and Bickford, M. E. 2004. Thrusting and extension in the Scandian hinterland, Norway: new U-Pb ages and tectonostratigraphic evidence. Am. J. Sci. 304:477-532.

Vander Auwera, J.; Bolle, O.; Bingen, B.; Liegeois, J.P.; Bogaerts, M.; Duchesne, J. C.; De Waele, B.; and
Longhi, J. 2011. Sveconorwegian massif-type anorthosites and related granitoids result from post-collisional melting of a continental arc root. Earth Sci. Rev. 107: 375-397.

Vrijmoed, J. C.; Van Roermund, H. L. M.; and Davies, G. R. 2006. Evidence for diamond-grade ultra-high pressure metamorphism and fluid interaction in the Svartberget Fe-Ti garnet peridotite-websterite body, Western Gneiss Region, Norway. Mineral. Petrol. 88:381405.

Wain, A. 1997. New evidence for coesite in eclogite and gneisses: defining an ultrahigh-pressure province in the Western Gneiss Region of Norway. Geology 25: 927-930.

Wain, A. L.; Waters, D. J.; and Austrheim, H. 2001. Metastability of granulites and processes of eclogitisation in the UHP region of western Norway. Journal of Metamorphic Geology 19:607-623.

Whalen, J. B.; Currie, K. L.; and Chappell, B. W. 1987. Atype granites: geochemical characteristics, discrimination and petrogenesis. Contrib. Mineral. Petrol. 95: 407-419.

Whitehouse, M. J. and Kamber, B. S. 2005. Assigning dates to thin gneissic veins in high-grade metamorphic terranes: a cautionary tale from Akilia, southwest Greenland. J. Petrol. 46:291-318.

Whitehouse, M. J.; Kamber, B. S.; and Moorbath, S. 1999. Age significance of U-Th- $\mathrm{Pb}$ zircon data from early Archaean rocks of west Greenland: a reassessment based on combined ion-microprobe and imaging studies. Chem. Geol. 160:201-224.

Wiedenbeck, M.; Allé, P.; Corfu, F.; Griffin, W. L.; Meier, M.; Oberli, F.; Von Quadt, A.; Roddick, J. C.; and Spiegel, W. 1995. Three natural zircon standards for U-ThPb.Lu-Hf, trace element and REE analyses. Geostand. Newsl. 19:1-23. 